\title{
HUKUK FELSEFESI
}

\section{AVRUPADA REFORM HAREKETİ VE MÜLKIYYET SORUNU}

Yazan : Doçent Dr. Adnan GƯRtz

\section{I - Feodal Diizen}

Reform hareketinin mülkiyet sorunu karşısındaki tutumunu incelemeye geçmeden önce, orta çağ Avrupa toplumunun feodal bünyesi üzerinde durmak zorunluluğu vardır. Çünkü reform hareketi feodal düzenin yıkılıs döneminde kendisini göstermiş ve bu hareketin iki önemli siması olan Luther ve Calvin'in mülkiyetle ilgili çeşitli fikirleri, içinde yaşadıkları sosyal, ekonomik ve kültürel ortamın etkisi altında kalmıștır.

Orta çağın başında, batı dünyasının en önemli özelliği, eşit olmayan gelişme seviyesindeki medeniyetlerin karşılaşması ve birleş. mesi olmuştur. Bir yanda, temelleri bakımından güçlükle tek bir birim sayılabilecek olan Roma dünyası dikkati çekiyordu. Roma medeniyeti çeşitli mahallî âdetleri içine almıştı ve bu âdetler türlü sosyal sunfflar arasında birbirine benzemeyen hayat sekillerinin belirmesinde rol oynamış bulunuyordu. Diger yanda, daha ilkel bir nitelik tașıyan Alman kavimleri göze çarpiyordu.

Bu dönemde devletin iflâsı önemli bir etken olarak ortaya çı. mıștı. Devlet fikri tamamen ortadan kaybolmuş ve silinmiş değildi. Insanlar, uzak bir hükümrandan himaye beklemek alışkanlığını kaybetmiş bulunuyorlardı. Bununla beraber, düzen ve onun sağla. dığı himaye ihtiyacı devam ediyordu. Insanlar bu himayeyi kendilerine sağlayacak yakın kişileri buldukları ölçüde, onlara, bağlanmakta tereddüt etmediler. Orta çă̆ Avrupa toplumunun siyasi yönden parçalanmış bünyesini devlet otoritesini kullanan çeşitli siyasal güçlerin çợalması ve gittikçe yayılması olayı ile açıklamakta herhangi bir yanlışlık olmadtı̆ı söylenebilir. 
Feodalizmin doğduğu sosyal ortamda mübadele tamamen yoktu denilemez. Bununla beraber mibadele'nin ekonomik hayattaki fonksiyonunun fazla önemli olmadığı söylenebjlir. Toprak, başlica zenginlik kaynağını teșkil ediyordu. Ticari ilişkilerin gelişmemiş olması, insanlarm kendi hâkimiyetleri altında bulunan toprak parçası ile geçinmeleri zorunluluğunu doğurmuş bulunuyordu. Alıs verişin bugünün toplumunda gördüğümüz gibi rahat şekilde yapiması imkânının mevcut bulunmaması, ücretli tarım ve endüstri sınıflarımın doğmasını önlüyordu.

Feodalizmin en gelişmiş şeklinin başlıca özellikleri, vasallık ve fief kurumlarıdır. Frank ve Lombard dönemlerinde dahi çeșitli tabakalara mensup bulunan hür insanlar, kendilerinden daha kuvvetli olan birisinin himayesini sağlamak ve hizmetlerini o kişiye vermek suretiyle, iyi bir hayat sağlamak yolunu araștırıyorlard. En fakir olan insanlar ise köle veya toprak kiracısı durumuna düşüyorlard.. Diğer taraftan senyörler kendilerine să̆lam şekilde bağlı sadık insanlara ihtiyaç duyuyorlardı. Bu durum feodal sistemin en önemli özelliği olan tâbilik anlaşmasının doğumunda başlıca rolï oynamışt1.

Cermen hukukunda vasallık ilișkisi, șeklî bir fjille gerçekleștiriliyordu. Vasal ellerini senyörün birleşmiş olan elleri üstüne ko. yarak sadakat ifade eden bazı sözler söylüyor, daha sonra da sen. yör ve vasal birbirlerini dudaklarından öpüyorlardı. Muhtemelen eski Cermen âdetlerinden gelen bu seremonide dinî herhangi bir özellik mevcut bulunmuyordu. Ancak bazı hallerde anlaşma daha başka șekillerde de yapıliyordu. Kendi toprağım senyöre vermek suretiyle senyörün himayesine kavuşmak istyen kimse, sadakat yemininden sonra, senyörden bir avuç toprak veya altm bir halka almak suretiyle tâbilik mukavelesini tamamliyor ve böylece elinde bulundurduğı toprağ fief șeklinde tekrar geriye alıyordu.

Senyör ve vasalın hakları ve ödevleri, mahalli âdetler ve örfler tarafından düzenleniyor ve devamlı değişmelere uğruyordu. Vasal, senyöre sadakat ve gerekli hallerde yardım borcu altında idi. Mad. di niteliği olan bu yardım borcu genellikle askeri bir karakter taşıyordu. Buna karşı senyör, vasalı devlet mahkemelerinin bulunduğu yerlerde hukukî bakımdan korumak, öldüğü zaman öksüz kalan çocuklarmı yetiștirmek ve nihayet vasala belli bir toprak vere. rek bu sayede geçimini sağlamak veya kendi malikânesinde, yedirmek ve barındırmak mükellefiyeti altında bulunuyordu. Senyörün malikânesinde bulunan vasallerin sayısı IX. ve X. yüzyıllarda 
önemli bir sayıya ulaşmakla beraber asıl uygulanan sistem senyörün vasala belli bir toprak vermek suretiyle onun geçimini sağlamasıydı. Senyör tarafindan vasala verilen toprağa başlangıçta beneficlum adı verildiği halde, zamanla Cermen âdetlerinin hâkimiyet kazanması sonucu olarak beneficium terimi yerini Alman asıh fevum veya feodum kelimelerinden gelen fief terimine bırakmışt1.

Feodal herhangi bir mükellefiyet altında bulunmayan toprağa «alodia» adı verilmişti. Ancak bu özelliği taşıyan toprak miktarı devamlı şekilde azalmış ve siyasi himaye zorunluluğu bu tip toprakların gittikçe küçülmesinde önemli bir rol oynamıştı.

Diğer taraftan, bir çok hallerde, senyörden fief elde eden vasal, kendi fief'i üzerinde başkalarına fief tanıyabiliyor ve böylece ayni toprak fief yoluyla multtelif vasallere bağlanabiliyordu. Teorik bakımdan, senyör'ün tesis edilen ikinci fief'e rıza göstermesi gerektiği halde, uygulamada onun muvafakati aranmiyordu. Bu uygulamanın doğurduğu sonuç, feodalizm'in şahsi bağllilk yanında mülkî bağlılı̆̆ da yaratması olmuştu.

Feodal sistemin temel unsurlarından birisi olan manor, senyörün malikânesini ve buna dahil tarım topraklarınt ifade ediyordu. Senyörün himayesine muhtaç bulunan kiracılar, kendilerine sağlanan himaye karşılığında, toprak gelirinin belli kısmını, kendilerinì himaye eden senyöre vermek borcu altında bulunuyorlardı. Bundan başka senyöre ait olan topraklar üzerinde karşılıksız çalışmak mecburiyeti toprak kiracılarına ve topraksızlara yüklenmişti. Senyör angarya (corvée) sisteminden de yararlanyordu.

Veraset usulü başlangıçta uygulanmamış ve hem senyörün, hem de vasalın ölümü halinde yeni bir tâbilik mukavelesinin yapılması zorunluluğu kabul edilmişti. Ancak, senyör, insana ihtiyacı olduğundan vasalın ölümü halinde, onun çocuklarının hizmetini değerlendirmek durumunda bulunuyordu. Bir koruyucu arayan vasalın çocukları da tâbilik mukavelesinin devamında fayda görüyorlardı. Bu sebebten, veraset usulü yavaș yavaș feodal sisteme katıldı ve gittikçe yaygın şekilde uyguland.

Feodalizmin ekonomik yapısında senyörden, vasalden ve ikinci derecedeki vasallarden sonra en alt kademede bulunan serfler toprakta çalıșmak, üretim işini gerçekleştirmek ve toprak el değiştirdiği zaman toprakla beraber sahip değiştirmek durumunda bulunuyorlard1. 
Tawney, Orta çă̆ toplum yapısının başlıca özelliklerini "sınıf ayrıcalı̆̆ı, sınıf baskısı, istismar ve serflik" olarak belirtilmekte (1) ve feodal mülkiyet sisteminden söz ederken de «feodal mülkiyetin esası açık istismara dayanıyordu. Çiftçinin kendi toprağında çalş̧mas - gerekli olan zamanda mecburi çalışmaya tâbi tutulması bunun en dikkati çekici örneklerindendir. Çeşitli mükellefiyetlerin yanı sıra, çiftçi buğdayını senyörün değirmeninde öğütmek, ekInç̆ini senyöre ait furında pişirmek ve senyör tarafından muhakeme edilmek durumundaydı» demektedir. (2)

Orta çağda yalnız tarım hayatında değil ayni zamanda ticaret ilişkilerinde de kendine göre özellik taşıyan kurumlar dikkati çekmektedir. Ticaret hayatında rol oynayan bu kuruluşlar lonca olarak biliniyorlard. Ticaret loncaları Cermen ülkelerinde gilde veya hansa, Latin ülkelerinde ise caritas veya fraternitas olarak isimlendiriliyorlard.

Ticaret loncalarının başlangıçı iradî birlikler oldukları ve XII. yüzyildan itibaren bunların ya bütün bir şehir ticaretini yü$\imath$ ütmek veya belli mallarnn ticaretini yapmak hususunda ayruca. lıklara sahip oldukları söylenebilir. Feodal senyörler ve șehir idareleri kısa zamanda ticaret loncalarınn faaliyetini tammak zo:unda kalmıslardı. Bu tanımada, ticaret loncalarına șehirlerin bütưn zengin tüccarlarının üye olması rol oynamış bulunabilir. Ticarî amaç taşıyan ticaret loncalarının yanında ve hiç olmazsa XII. yüzyıldan önce sanatkâr loncalarının kurulduğu ve bu loncaların latince officium veya ministerium kelimeleri ile ifacle edildikleri bilinmektedir.

Sanatkâr loncalarının kaynağının nerede aranması gerektiği, halâ çözülmemiş bulunan tartışmalı bir sorundur. Bu hususta birhirinden farklı üç ayrı görüs savunulmuştur. Birinci görüșe göre, sanatkâr loncalarminn kaynağı, Roma İmparatorluğı devrinde şehir sanatkârlannın kurdukları collegia ve artes olarak isimlendirilen birliklerde aranmal1dır. tkinci fikir, Carolingler devrinde ve bu devirden sonra, senyör adına çalışmak üzere serflerden kurulan birliklerin sanatkâr loncalarmın ilk şekli olduğgunu savunmaktadır. Ancak șehirlerin geliştiği sırada kaynağı kölelik olan birliklere çok sayıda insanın katılmasının ve daha sonra bunların sanatkâr lencaları haline gelmesinin mümkün olamıyacă̆ı ilcri sürülerek bu gö-

(1) Tawney, R. H. Religion and the Rise of Capitalism, London 1938 p. 37.

(2) Tawney, R. H. op. cit., p. 67. 
rüşün reddine çalışllmıştır. Üçüncü teze göre, sanat loncalarının kaynağı, sanatkârların, tüccarların örneğini izleyerek birleşmeleri olayında aranmalıdır. Modern yazarlarun çoğunlukla bu son görüişü benimsedikleri bu vesile ile belirtilebilir.

Orta çağda siyasi yöneticiler, Roma geleneğine uygun olarak, pazarları idare etmek, ağırlıkların ve öIçïlerin kontrolünü yapmak, vergi yüklemek ve uyuşmazlıkları çözümlemek ödevlerini yerine getirmişlerdir. Merkezi iktidarın IX. yüzyıldan itibaren süratle çökmesi bu durumu değiştirmemiş ve senyörler hâkimiyetleri al. Inda bulunan şchirlerde, devlete ait yetkilert kullanmışlardır.

Avrupada, XI. yüzyılın başlarından itibaren şehirlerdeki esıaf yaptıkları işe göre gruplara ayrılmış ve her grup belli bir sanatın. yalnızca kendi üyeleri tarafından yürütülmesi hakkını kazanmış bulunuyordu. Başlangıçta sanatkâr loncalarının üye olmayanların rekabetine kar\$̧ı kullanabileceği herhangi bir hukukî yetki mevcut bulunnuyordu. Ancak zamanla loncalar, uiye olmáyanlar ya üyeligie girmeye mecbur tutmak veya sanatı terketmek șlklarıyla karșı karşıya bırakmak yetkisini elde ettiler, Bu yetkinin kazanılmasında, şehirleri yöneten senyörlere veya kurullara ayrıcalık karşılığın. da ödenen para önemli bir rol oynamıștır. Esnaf veya sanatkár lon. calarının heryerde tam bir özerkliğe sahip olduğunu söylemek ve siyasi otorite karşısındaki durumlarında özdeşlik olduğunu belirtmek doğru olmaz. Bununla beraber bu kuruluşlarm ekonomik yapıları hemen heryerde birbirine benziyor ve orta çağ şehir ekonomisinin ortak özelliklerini yansıtıyordu. Esnaf loncalarının en büyük özelliği, sanatkârı yalnızca diğer șehirlerin değil, fakat ayni zamanda baskka sanatkârların rekabetine karşı korumasunda belir. mektedir. Şehir pazarına katılma hususunda, esnaf, lonca sayesinde bir imtiyaza sahip bulunuyor ve ayni zamanda lonca üyelerinin diğer üyeler zararına zenginleşmesi de önleniyordu. Çalıșma saatleri, ücretler, mal fiatları, her dükkânda kullanılan alet ve çalıștırılan iısan sayısı lonca tarafından tesbit ediliyor, reklảm yasağı lonca tarafından uygulanıyordu. Lonca üyeleri arasında eşitliğin korunmasma daima önem veriliyordu. $\mathrm{Bu}$ sistem, üretim metodlarının geliştirilmesi ve daha ucuz üretim imkânlarının araştırılınası yönüuı̉en fazla yararlı bir nitelık tașımıyordu.

Feodal füzenin en önemli özelliği olan hiyerarşi,lonca teşkilâtında da mevcut bulunuyordu. Esnaf Ioncalarında sanatkârlar usta, kalfa, çırak olmak üzere üç grupa ayrıJmıştı. Dükkânda kullantan ảletlerin ve ham maddenin mâliki olan ustalar lonca hiye- 
rarşisinde en yiuksek yeri işgal ediyorlardı. Çiraklıktan kalfalığa gç̧is fazla güç olmamakla beraber ustalık mertebesine erişmek oldukça zordu. XIV. yüzyıldan itibaren ustalık derecesine ulaşmak daha da güçleşmişti. Kalfaların sayısının günden güne çoğalması bunlarm durununun kòtüleşmesinde rol oynamış ve XV ile XVI. yüzyllarda kalfaların durumu gündelikçi işçinin durumuna gittikçe daha fazla benzemeye bașlamıştı. Bu sebebten XV. ve XVI. yüzyıllarda lonca teşkilâtını ele geçirmek isteyen kalfaların, çeşitli şiddet hareketlerine giriștikleri görülmüş̧tü.

Erich Fromm, orta çă̆ toplumunda lonca teşkilâtının fonksi. yonunu şöyle belirtiyor: «Orta çă̆ toplumunda ફehrin ckonomik organizasyonu oldukça statikti. Sanatkârlar orta çă̆ın ikinci yarısındanberi loncalarda birleşmiş̧erdi. Her ustann bir veya iki ç1rağı vardı ve ustaların sayısı, toplumun ihtiyacına göre değişiyordu. Varlığını devam ettirmek için çok çalıșması gerekenler bulunmakla beraber, lonca üyeleri genel olarak kendi ellerinin emeği ile yaşayabileceklerine inanıyorlardı..... Loncalar kendi üyeleri ara. s.nda kuvvetli bir rekabetin belirmesini önlïyorlar ve üyelerini hamme madde satın alınması, üretim tekniği, üretilen malların fiyatları hususunda işbirliği yapmaya zorluyorlardı.»

Ticaretin genel olarak küçük tüccarlar tarafından yapılması, toptancı ve perakendeci sıfatlarının ayni șahısta birleșmesi, ticaret hayatma belli bir kararlılık sağlıyordu. Küçük is adamları, orta çağın sonunda büyük kapitalin ve tekelci ticaretin gelişmeye başla. dığı zamana kadar göze çarpan bir güvenlik içinde bulunuyorlardı.

Orta çağ ekonomik düzeni karșısında kilisenin durumu üzerinde de de durmakta fayda vardır. Orta çağ ekonomisi geniş ölçüde tarıma dayanıyor ve insanların büyük çoğunluğu geçimini tarım üretimi sayesinde sağllyordu. Tarım ekonomisi ise, bu kolda ça. Iışanların büyük çoğunluğunu serf haline getirmiș bulunuyordu. (4) Tarım topraklarının önemli bir kısmının gelirine sahip bulunan kilise, uygulanan sistemin haklılığını veya haksızlı̆ı̆ını tartışmak imkânından mahrum bulunuyordu. Çünkü mevcut mülkiyet sisteminin tartıșılması, kilisenin büyük gelir kaynağını tehlikeye düşürebilirdi. Ancak orta çağda hiç olmazsa teorik olarak ahlâki bir amaca yönelmeyen bütün ekonomik faaliyetlere şüpheli bir gözle

(3) Fromm, Erich. Fear of Freedom, London 1960, pp. 43, 44

(4) Tawney, R. H. op. cit., p. 66, Tawney, orta çağda insanlarm onda dokuzunun tarımla uŏraştığın ifade etmektedir. 
bakılıyordu. Maddi zenginliklerin ikincii derecede de olsa gereklili$\breve{g} \mathbf{i}$ kabul ediliyor ve bunlar olmaksızın insanların kendilerini besleyemiyecekleri ve birbirlerine yardım edemiyecekleri belirtiliyordu. Her insanın sosyal durumu için gerekli bir refah seviyesine erişmeyi istemesi ve bunu sağlamak için çalışması hakkıydı.. Ancak gerekli olandan daha fazlasın istemek hırstı ve hırs dine göre günahtı. Çeșitli memleketlerin, farkh zenginlik kaynaklarma sahip bulunmaları ticaretin Tanrı tarafından istendiğinin kanıtı sayılıyordu. Bununla beraber ticari faaliyetin yürütülmesinde toplum yararinun güzz önünde tutulmasıs, yüksek kâr yoluna başvurulmaması lüzumluydu. Özel mülkiyetin günah mahsulü olan bu dünya için gerekli olduğu söyleniyordu. Mallar özel mülkiyete konu oldukları zaman insanların daha fazla çalıștıklarına ve daha az çatıştıklarına inamlyyordu. (5)

Bununla beraber orta şağ teorisi, hayatun asıl amacı olan insanın kurtuluşu üzerinde daima israr etmiş ve ekonomik faaliyetlere, kişinin ruhî ve dinî hayatından sonra gelen ikinci derecede bir yer ve önem vermiștir.

\section{Reform Öncesi Avrupa Toplumu}

Rcform öncesi Avrupasunda ticaret hayatumn feodal ticaret hayatına kıyasla büyük farklılıklar gösterdiği söylenebilir. Orta çă̆ ticareti esas itibariyle şehir içi karakter taşıyordu. Buna karşı millî ve milleticrardsı ticaret, XIV. ve XV. yüzyıllarda süratli bir gelişme

(5) Orta çă̆ katolik mülkiyet anlayıșımı St. Thomas Aquinas oldukça açık bir șekilde belirtmiștir. Ona göre, özel miilkiyet kurumu lüzumludur. Çünkü inșan, yalnızca kendisine ait olan mallar üzerinde üretim faaliyetinde bulunmak hususunda daha isteklidir. Çalışmanın zorluğu dolayısıyla insanlar, toplum için istibsalde bulunmaya fazla hevesli değildirler.

Bundan başka, herkes kendine ait olana sahip olursa insanlarnn hayatı daha düzenli olur. Eğer insandan topluma ve başkalarına ait olan şeyler konusunda dikkat ve çaba istenirse karısıllık doğabilir.

St. Thomas Aquinas, özel mülkiyet kurumunu meşrulaştırmak için üçüncü bir kant daha belirtmektedir. Herkes kendisine ait olanla tatmin edildiği zaman toplumda daha sağlam bir barış sağlanabilir.

Bununla beraber genellikle kabul edilen görüss, St. Thomas'in sisteminde mülkiyetin tabii değil, pozitif bir hak oldư̆udur. Dolayısıyla devletin mülkiyet hakkın düzenleme yetkisi kabul edilmiş olmaktadir. Diğer taraftan St. Thomas faizi reddetmiş, aç kalan bir insamn hrrsızlık yapmasının hukuka aykırı sayılmaması gerektiǧini savunmuștur. Bk. Symth, Frederic Hastings. The Midde Ages, editor: Fletcher, J. F. Christianity and Property, Philadelphia 1947, pp. 84-92. 
gösterdi. Tarihçiler, biiyuik ticaret şirketlerinin ne zaman gelişme. ye bașladığ 1 konusunda görüş birliğine varmış değildinler. Bununla beraber ticaret şirketlerinin XV. yüzyllda gittikçe kuvvetlendikleri ve tekeller meydana getirdikleri açıklıkla belirtilebilir. Bu şekilde gelişen şirketler hem küçük tüccarı hem de tüketiciyi tehdit eder bir duruma gelmiș bulunuyorlard.

Bundan başka sermayenin endüstrideki öneminin gittikçe ge. liştiğine retorm öncesi Avrupa toplumu tanık olınaktadır. Bu konuda en ilginç örneklerden birisi maden endüstrisidir. Başlangıçta maden loncası üyelerinden herbirinin payı yaptıkları ișe göre değişiyordu. Ancak XV. yüzyıldan önce, çoğu zaman, maden ocaklartnın payları çalışmayan sermaye sahiplerine ait bulunuyor ve üre. tim gittikçe çoğalan şekilde teșebbüste pay sahibi olmayan işçite tarafından yapilıyordu. Ayni değişme, diğer endüstri alanlarmnda da görünìyor ve zengin ile fakir arasındaki ayrılık ve fakir sınıflar arasındaki hoşnutsuzluk çoğalıyordu.

XIV. yüzyldan itibaren loncalar arasında gittikçe büyüyen bir farkhlık belirmeye bağlamış̦tı. Bazı esnaf loncası üyeleri diğerlerinden daha fazla sermayeye sahip bulunuyorlar bir veya iki kiși yerine beş veya altı kiși çalıștırıyorlardı. Bir süre sonra bazı loncalarm, ancak belli bir sermayeye sahip olanları lonca teşkilâtma kabul etmeye başladıkları görüldü. Bazı loncalar ise tekelleşmek ve müş̧teriyi mümkün olduğu kadar çok sömürmek yolunu tuttular. Diğer taraftan lonca mensuplarının çoğunluğı meydana gelen de. ğişme yüzünden fakirleşmeye başladılar ve kendi geleneksel sanatları yanında diğer ișleri yaparak hayatlarını sürdürme zorunluluğu ile karşı karşıya kaldılar. Lonca sistemindeki bu değiş̧me, özellikle kalfaların durumunun gittikçe kötüleşmesinde rol oynadı.

Ticarct hayatındaki bu önemli gelişmede ve değișmede yeni ülkelerin bulunmasının, denizașın ticaretin ilerlemesinin ve özellikle Amerika kıtasından Avrupaya çok miktarda altın ve gümús madeni gelmesinin etkili olduğunu ayrıca belirtmek gereklidir.

Çiftçinin durumunun da XVI. yüzyllın başlarında süratle kö. tüleştiği görülmektedir. Burların büyük kısmı, toprağa çeșitli mükellefiyetlerle bağlı bulunuyorlar ve yüklendikleri ödevlerin gittikçe fazlalaştı̆̆ını görüyorlardı.

XVI. yüzyıl ekonomik hayatının doğurduğu şartlar orta çă̆ sınıf yapısını temelinden sarsıyor, sermayenin, pazarm, rekabetin rolü gittikçe büyüyordu. Bu rolün XVI. yüzyılda, daha sonraki dö- 
neme göre daha az önemli olduğu doğru olmakla beraber, modern kapitalizmin bïtün unsurları ortaya çıkmıș bulunuyordu. (6)

Ekononik hayatta meydana gelen hareket ve dalgalanma orta çašın sınıf yapısı üzerinde önemli tesirler meydana getirmiș, fakir sınıfları daha fakir hale sokmuș, orta sınıfın az gelirli zümresinin durumunu sarsmış, küçük aristokrasiyi buhran içine atmış, kilisenin iktisadi kuvvetine karşı olan muhalefeti arttırmış ve yeni fikirlerin ortaya çlkmasına ve gelişmesine elverişli bir ortam hazırlamıș bulunuyordu.

Reform hareketinin doğumunu hazırlayan sosyal ve ekonornik seheblerin yanmda, bütün orta çă̆ boyunca devam eden kilise ve devlet muicadelesi, kilisenin üstünlü̈̆üine karșı cephe alan siyasi yöneticiler için elverişli bir ortamı yaratmıștı. Kilise ve servet aris. tokrasisi dișında kalan bütün sınıflar, reformu desteklemeye istek. liydi. Bundan başka, rönesans hareketi zengin ve kuvvetli smıfın kültür ihtilâlini temsil etmekle beraber, eski Yunan ve Roma mede. niyetine ait bazı değerlere bir dönüşìn ifadesi olmuş ve insana evren içinde bağımsız bir yer sağlama amacını gütmüştü. 1516 yılında Erasmus'un kutsal kitabı çevirmesi fikir alanında rönesansla başlayan hareketi güçlendirmiş ve dinî bir reform için gerekli psikolojik ortamı hazırlamıștı.

\section{Luther ve Özel Müilkiyet Sorunu}

Luther, katolik kilisesine karşı orta çağın bütün şikâyetlerini "Alman Aristokrasisine Hitabe" isimli bildirisiyle açıklamıştır. Bu bildiri, orta çą boyunca kiliseye karsı yapılan tenkidleri bir araya getiriyor ve kuvvetli bir dille açılıyordu. Papazlık görevinin satılması, kilise büyüklerinin siyasi kudret sahiplerinin hayal bile edemedikleri bir hayatı yaşamaları, manastır hayatında olması gerekli fakirlik ve ahlâklılık ile manastırlarda yaşanılan hayat arasındaki farklılık, çiftçiden imparatora kadar herkesi fakirleştiren papalığın el koymaları, Luther tarafından şiddetle tenkid ediliyordu. (7)

Luther aynca, Roma Kilisesi'nin Tann bağışlaması konusunda herhangi bir tekele sahip olmaması gerektiğini ifade ediyor ve kilisenin zenginliğini tenkid ediyordu. Manastırlarda biriken ser.

(6) Fromm, Erich. op. cit, pp. 51, 52.

(7) Schlatter, Richard. Private Property, London 1951 p. 81. 
veti tenkid ederken Luther, «manastır keşişleri çalışmadıklarına göre, nuïrrffeh bir hayat yaşamaları için herhangi bir sebeb de mevcut değildir» diyordu. Luther'in görüşüne göre, zenginlik ancak çalıșma ile elde edilebilmelidir. Bazı insanların çalışması ve diğer insanların çalışmadan yaşamaları adalete aykırıdır. Bu konuda Luther St. Paul'e de başvurmakta ve onun «bir insan çalışmazsa yememelidir de» yolundaki ifadesini kendi tezini kuvvetlendirmek için tekrarlamaktadır. (8)

Luther'in mülkiyet konusundaki fikirlerinin en ilginç tarafı, ilk Kudüs kilisesinin uygulamasına da etkide bulunan, ortak mülkiyet anlayıșinı reddetmesinde belirmektedir. Luther'e göre, Tanrının dünyayı ve onun ürünlerini bütün insanlara verdiği yolundaki esasları tekrarlamak için herhangi bir sebeb yoktur. İncil'de de mulkiyetin ortak olduğunu belirten herhangi bir beyan bulunmamaktadır. Îlk hıristiyanların bazıları kendi istekleriyle mallarını birleş. tirmişlerdir. Fakat başkalarma ait malları ortak yapmak yolunda herhangi bir çaba harcamamışlardır. (9)

Luther, mülkiyetin tabii hukuk gereğince ortak olduğu görüșünï kabul etmemekte ve bu görüsşe karşı teolojik bir kanıta baș. vurmaktadır. Ona göre, tabii hukuk ve on emir birbirinin aynıdır. On emir arasında yer alan «hrrsızhk yapmayacaksın» ilkesi özel mülkiyetin temeli sayılmalıdır. Hırsızlığın yasaklanması özel mülkiyetin din tarafından meşru ve muteber sayıldığının açı ifadesidir. Tabii hukuk ile on emrin ayni olduğunu savunmak ve tabii hukuka bağımsız bir yer vermemek suretiyle Luther, St. Thomas Aquinas'in tabii hukula ilgili bütün fikirlerini reddetmiş ve katolik görüşünden tamamen ayrılmıs oluyordu. Luther, mülkiyetin tabii hukuka ve insan aklına dayandığı yolundaki kanıtı reddetmek suretiyle, orta çă̆ teolojisinin üzerinde durduğu, incelediği ve eski Yunan felsefesinden yararlanarak derinleștirdiği bir konuyu basit bir kanıtla çözümlemek yoluna başvurmuş bulunuyordu. Tabiatıy. la onun bu tutumu, katolik yazarlar tarafından daha sonra șiddetle tenkid edilmesine sebeb olmuș ve kendisi, önemli felsefî prob. lemleri anlamamakla suçlanmıştır.

Gerçekte, Luther, St. Thomas Aquinas'a karșı St. Augustine'nin kötümser dünya ve hayat felsefesinden ilham almıştı. Aslında özel mülkiyet kurumu da, devlet gibi, insan günahımın bir sonucu sayıl-

(8) Schlatter, Richard. op. cit., p. 82.

(9) Schlatter, Richard. op. cit., p. 90. 
mak lâzımdı. Insan mükemmel bir yaratık olsayd1, yeryüzünde eșitsizliğin ve cebrin bulunmaması gerekirdi. İnsanlar böyle bir olgunluk seviyesine erişemędikleri ve erişemiyecekleri içindir ki, özel mülkiyet kurumu, Luther'e göre gerekli bulunmaktadır. Devlet nasıl lüzumluysa, özel mülkiyet de lüzumludur. Aklî bir dalâlet içinde bulunan insanoğlu'nun, tabii hukuka ve tabii haklara başvurması ve davranışlarını bunlara göre düzenlemeyi istemesi, hiçbir zaman doğru değildir.

Siyasal bilimcilerin eskidenberi belirttikleri gibi, Luther siyasi iktidara karşı ayaklanma şeklindeki bir hak üzerinde durmamış, insanlara «prensin en zalim davranıșlarına karşı bile itaat ve sabır» tavsiyesinde bulunmuştur. Ancak kabul etmek gerekir ki, halka prensin otoritesine itaat tavsiye eden Luther, prensin ödevini adalet esaslarına göre yapmasınt istemiştir. Luther'in sisteminde prensin mülkiyeti kısıtlama hakkının bulunup bulunmadı̆̆ı, eğer varsa, bu hakkın sınırlarının nereye kadar uzadığı sorunu üzerinde de durulabilir. Luther bu konuda açık bir tutum takınmıș değildir. Onun bu konudaki belirsizliği ölümünden sonra önemli bazı uyușmazliklarm ortaya çıkmasına sebeb olmuştur. Almanya da katolik prenlerin protestanlara ait mallara el koymaları halinde, protestanlarm bu el koymalara karşı koyup koyamıyacakları, Lutherciler tarafından tartışılmıştır. Bu konuda en dikkati çekici karar Magdeburg șehri Luthercileri tarafından verilmiştir. Onların kanısına göre, el koymalara protestanların kuvvet yoluyla karșı durmaları gerekmevebilir. Ancak el koymaya kuvvetle engel olmanın hukuka aykırı olduğu da söylenemez. (10) Dikkat edilirse varılan sonuç, Luther'in görüșii ile direnme hakkını uzlaștırma niteliğini tașımıştir.

Luther mülkiyet hakkı üzerinde dururken, evlenmenin sosyal yönden zorunluluğunu belirtmis ve özel mülkiyet olmaksızın düzenli bir aile hayatmın imkânsız olduğu fikrini de savunmuștur. (11)

Luther, çeşitli fursatlardan yararlanarak müikiyetle ilgili görüșlerini açıklamış ve özellikle bu hakkın kullanılması konusunda kendi taraftarlarının karşılaştıkları problemleri çözmeye uğrașmıștır. Bu sebebten Luther'in mülkiyet hususunda düzenli bir teori meyadana getirmediği söylenebilir. Onun fikirlerini sistemleştirmek işini arkadaşı ve takipçisi Melanchton yapmıștır.

(10) Schlatter, Richard. op. cit., p. 93.

(11) Schlatter, Richard, op, cit., p. 87. 
Melanchton, Luther'in görüşlerini Loci Communes (Ortak Konular)isimli eserde özetlemiştir, Melanchton, ilk önce bütün hukuku, ilâhi, tabii ve insanî olmak üzere üçe ayırmıştır. Ona göre, Insanın günahkâr özelliği yüzunden, tabii hukuku, mukaddes kitaplara başvurmadan bulup bulamıyacağı șüphelidir. Hukukun ilkele. rini yalnızca insan aklında arayan düșünürler yanlışlığa düşmüș. lerdir. Huristyan filozof üç tabii kanun tanır. Bunlar, Tanrıyı saymak, hiçkimseye zarar vermemek ve herşeyi ortaklaşa kullanmak. tır. Ancak dalâlete dïșmüş olan insanoğlunun bu kaidelere uyması mümkün değildir. Dünya için geçerli dört tabii kanundan söz edilebilir. Bunlar, Tanrının sayılması, kimseye zarar verilmemesi, suçluları cezalandıracak ve mâsumları koruyacak idarecilerin tayinine imkân verilmesi ve nihayet mülkiyetin bütün insanlar arasında barışı sağlayacak şekilde dağıtılmasıdır.

Melanchton, ister ius naturale'den ister ius gentium'dan çıa. rılsın, mülkiyetin tabii bir kurum olduğu görüșünü benimsemektedir. (12) Tabii hukuk değişmez bir nitelik taşır. Bu hukukun asli ve tâli ilkeleri arasında bir çatışma olduğı zaman, aslî ilkelerin tercih edilmesi gerekmekle beraber, insan tabiatının dalâleti dola yısıyla özel mülkiyet kurumunun kabulü zorunludur. Melanchton malların insanlar arasında bölüisülmesinin insanoğlunun eseri olduğunu ve bölüșme olduktan sonra on emirle Tanrı tarafindan kutsallaștırıldığını ileri sürmektedir. Bu sebebten malların insanlar arasında dağılımı ebediyyen devam edecektir. Melanchton da, üstadı Luther gibi mülkiyet kurumunu on emrin «hırsızlık yapmayacaksın» esası ile meșrulaștırmaktadır. Ölümden sonraki hayatta lerşey ortak olacaktır. Dünyadaki hayat için ise insanların özel mülkiyete sahip olmaları Tanrı iradesine uygundur. (13)

Siyasi iktidarm mülkiyeti hangi ölçüde smırlayabileceği husunda Melanchton, Luther'e nazaran daha açık bir teze sahip bulun-

(12) St. Thomas Aquinas'ın teorisinde mülkiyetin tabii bir hak mı yoksa pozitif bir hak mı olduğu sorunu tartışmalıdır. Melanchton, katolik düșünürler gibi ius gentium'un tabii hukukla ayni șey olduğunu ka. bul etmektedir. Bagi, Louis La garantie constitutonnelle de la propriété, Lausanna $1956 \mathrm{pp} .52,53$ de ius gentium ve ius naturale terimlerinin St. Thomas Aquinas tarafından eş anlamda kullanıldığın belirtmektedir. Friedmann ise St. Thomas Aquinas'ın mülkiyete hiçbir zaman bir tabii hukuk kurumu gözü ile bakmadığını söylemekte ve katolik doktrinin St. Thomas Aquinas'ın yanlış yorumuna dayandığını ifade etmektedir. Friedmann, Legal Theory, London 1953 p. 32.

(13) Schlatter, Richard. op. cit., p. 97. 
maktadır. Kıral tebaya vergi yükleyebilir. Bazı hukuk sistemlerinde, kıralın vergi alma hakkı smirlıdır. Diğer bazı ülkelerde ise, verginin miktarını tayin hususunda hükümdar tamamen serbesttir. Hüküimdarın vergi yüklemek hakkı tartışma yapılmaksızın kabul edilmelidir. Ancak hükümdar mallara el koymak veya mallarm bö. lüşüm şeklini değiștirmek yetkisine sahip deł̧ildir. Bir insanın malları üzerindeki mülkiyet hakkı, ius naturale, ius gentium, on emir ve pozitif hukuk tarafından daima kabul edilir. Bütün bu esasları hiçe sayan bir hükümdar, zulüm ve günah yoluna girmiş sayılmalıdir.

Luther fikirlerini açıklarken daha çok orta sınıfın görüşlerini yansıtmıştır. XVI. yüzyılda orta sınıf bir yandan kilise otoritesine karşı duruyor, diğer yandan da ekonomik bakımdan gittikçe zenginleşen tiiccar sınıfına içerliyordu. Protestan hareketinin geniş anlamda bu sınıfı temsil ettigini söylemekte herhangi bir yanlıșlık yoktur. Luther 1524 yılında yayınladığı "Ticaret ve Faiz Hakkında" başlıklı broşüründe büyük tüccarlara karşı küçük tüiccarların ve tüketicinin çıarlarını şöle savunmaktadır : «Tüccarlar bütün faydalı malları hâkimiyetleri altında bulundurmakta, bütün hileleri aralıksız uygulamaktadırlar. Fiatları isteklerine göre yükseltmek1e, indirmekte, küçük tüccarları baskı altında tutmakta ve mahvetInektedirler..., sevgi ve inancın kaideleri dışına çıkmaktadırlar...» (14)

Luther'in görüşlerinin fakir insanlar üzerindeki etkisi daha farklı olmuştur. XVI. yüzyılın başlarında ekonomik bakımdan çok ağır bir baskının altında bulunan çiftçiler Luther'in "hıristyanların hürriyeti» ilkesini daha değișik şekilde yorumladılar. Luther'in kilise otoritesine hücum etmesini yürekten desteklediler ve bu şekilde içinde bulundukları ekonomik baskının azalacağını ümid ettiler. Çiftçilerin başlıca talebleri, rahiplerin halk tarafından seçilmesini, orman ve mera'lardan serbest șekilde faydalanmayı, balık avlama üzerindeki sınırlamaların kaldırılmasını ve en önemli olarak da toprak üzerindeki ağır mükellefiyetlerin hafifletilmesini kapsiyordu. Luther başlangıçta, siyasî otoritelerle çiftçiler arasında bir uz. laşmaya varılmasını istedi. Ancak böyle bir anlaşmanın yerine şiddet hareketlerinin başladığını görünce, çiftçi isyanlarının hertürlii vasitalarla bastırılmasinı savundu.

Katolik kilisesine karșı büyük bir antipati beslemesine rağmen

(14) Fromm, Erich, op. cit., p. 48. 
Luther papanın ve katolik din adamlarının öldürülmesini hiç bir zaman kendi taraftarlarına tavsiye etmediği halde, ihtilâlci köylïleri gơrür görmez öldürmelerini bütün Almanlardan istemekte te. reddüt etmemişti. Schlatter bu konuda diyor ki : "Luther'in ihtilâlci köylülere karşı olan bildirileri o kadar canavarca bir karak. ter taşımıștır ki, protestanlar o zamandanberi bu konuda özüı dilemektedirler," (15)

Reform sirasinda, Luther'in ve onun yolunu takip edenlerin uğraşmak zorunda kaldıklanı köylü ve çiftçi ihtilâlleri, çeşitli gruplar tarafından destekleniyor ve farkh doktrinlerce meşrulaș. tırliyordu.

Bu cereyañiar arasında en ateşli olanlar ve sosyal düzenin derhal değiştirilmesini savunanlar dinci karekter taşıyan sosyalist hareketler olmuştu. Anabaptistler ve anabaptisme bağh diğer bazı mezhepler mal ortaklığı rejimini az veya çok kuvvetli şekilde gerçekleştirmeye çalışıyorlardı. (16) Anabaptizm (17) açıkça eşitç̧i ve ortakçı ideal bir hıristyanlık toplumu kurmak amacumı tașıyordu.

Moravyalı Kardeșler (les Frères Moraves) (18) karșllıkl yardım ve hizmet esasına dayanan bir hristyan toplumu yaratmak gayesinde birleşmișlerdi. Sosyal yardum esasından herhangi bir tâviz vermemeye özellikle dikkat ediyorlardı. Bn cereyan, reformcuların görüșüne teorik yönden daha yakın fikirler savunduğu için hoşgörüi ile karșlandı ve mevcudiyetini uzun süre devam ettirebildi.

(15) Schlatter, Richard. op. cit., p. 78.

(16) Bićler, André. La pensée économique et sociale de Calvin, Cenève 1959, p. 388.

(17) Anabaptistler yalnızca çocuk vaftizini reddettikleri için değil, diğer bazı noktalarda da Luther'den aynildıkları için önem taşırlar. Bu akıma taraftar olanlar, ferdî kararm bă̆ımsızlığı ve hürriyeti yanında inanç unsurunun din bakımından önemi üzerinde de durmuşlardır. Zwickau'nun Lutherci rahibi Thomas Münzer, 1525 ytlinda başlayan büyük bir çiftçi ihtilâlinin lideri olmuştur. Anabaptizm'in kurucusu sayllan Muinzer'in giriștiği ortakçı toplum tecrübesi, Frankenhausen șehri. nin isgali ve kendisinin öldiirülmesiyle neticelendi. Ancak anabaptistler Münzer"in ölümünden sonra da frrsat buldukça ihtilâl tecrübesine girișmekten geri kalmadılar. 1532 yılında Münsterde başlayan ikinci ayaklanma, 1535 yllında şehrin işgali ve anabaptistlerin katledilmesiyle bastirild.

(18) Bu akım bazan "Frères Bohêmes" veya «Frères Tchèques» olarak da isimlendiriliyor ve Bohemyalı reformcu Huss'a bağlı bulunuyordu. 
Bundanbaşka sözü geçen akımın taraftarları, reformcular gibi özel mülkiyet kurumunun muhafazası gerektigine inanyorlardı.

Libertenler (les Libertins) özel mülkiyeti açıkça reddediyorlar ve bütün adaletsizliklerin kaynağının bu kurum olduğunı ileri stirüuyorlardı. Kısmen rönesansın tesiri altında kalan libertenler, insanların tabii temayüllerine uygun şekilde davranmak hürriyetine sahip olmalarını ve cinsel hayatta serbestlik fikrini aşlamaya gayret ediyorlardı. Ancak bu akım, aksiyondan çok fikir alanında kaldığı için etkileri sınırlı olmuştu. Calvin'in bu akıma bağlı olan. ları panteizmle ve ahlâkı hiçe saymakla suçladı̆̆ı bilinmektedir.

Luther, bir taraftan kilise mallarma el konulmasını haklı göstermek, diğer taraftan da mülkiyet hakkını aşırıların hücumuna karşı korumak zorunluluğu ile karşı karşıya bulunuyordu. Reformun muhaliflerinin Anabaptist hareketinden Luther'i sorumlu tutmaları da Luther'in bu akıma şiddetle karşı koymasında rol oynamiştır. Gene unutmamak gerekir ki, Luther, temsil ettiği orta sı. nıfın haklarını ve çıkarlarını savunmasının protestanlığın zaferi için kaçınılmaz olduğunu anlamıştı. Hiç şüphesiz Luther'in orta çağın gelenekçiliğine bağlılı̆̆ı da doktrininin tutucu bir özellik taşımasında etkili olmuştu. Luther'in sisteminde dinî radikalizm ve sosyal konservatizm birleşmiş bulunuyordu. (19) Ayni tutuculuk onun büyük tüccarlara karşı olan hüicumlarinda da dikkati çekmektedir. Fromm, Luther'in ekonomik konulardaki fikirlerinde orta çağ gelenekçiliğine bağlı kaldığını şöyle belirtiyor: «Luther'in ekonomik sorunlar hakkındaki görüşü tipik şekilde orta çăg vasfını taşıyordu.... Insan hayatının ekonomik gaye için bir araç haline gelmesi fikrinden nefret ederdi ...) (20) Bu vesile ile Luther'in en takdire deger hayat şekli olarak köylünün hayatını benimsediğini, insanı așındırıcı ticarî hesaplardan uzak yaşamayı ögüt verdiğini ve insanların, kaderin çizdiği yolda yürümelerini istediğini belirtebiliriz.

Luther'in mülkiyet görüșü, ana hatları bakımından, orta çağ mïllkiyet anlayışından fazla ayrılmıș değildir. Özel mülkiyet kurumunun lüzumuna Luther inanyordu. Bumunla beraber bu inanç, mülkiyet kurumunu ve ferdin ekonomik faaliyetini ön plânda de. gerlendirmesini gerektirmemiştir. Reform hareketi mülkiyet anla. yışının, kapitalist mülkiyet fikrinden ayrıldı̆̆ını Lehmann açıça ifade etmiştir. Lehmann'a göre: «Reformcular mülkiyeti hiçbir za-

(19) Tawney, R. H. op. cit., p. 95.

(20) Fromm, Erich. op. cit., p. 71. 
man inhisarrî bir hak saymamışlardır. Reformcu mülkiyet görüşü. nü, kapitalist mülkiyet anlayışından ayıran bașlica özellik budur. Aradaki fark kesin olarak şöyle belirtilebilir. Reformculara göre, «bir șeyi kullanma ve ondan yararlanma hakkı, mülkiyet hakkının muhtevasın belirtir. Halbuki kapitalist doktrine göre, mülkiyet hakkı, kullanma ve intifa haklarını tayin eder.» (21) Gerçekten, Luther ve takipçilerinin mülkiyet hakkını mutlak ve sınırsız muhtevalı bir hak olarak tanımlamak eğilimini gösterdikleri söylene. mez.

Luther'in iktisadi fikirlerinde orta çă̆ görüşüne bağlı kaldığını gösteren diğer bir örnek, çiftçi ihtilâllerini ayıpladığı şiddetle faizciliği yermesinde ortaya çımaktadır. Onun anlayışına göre, faiz kurumu yalnızca ilâhî hukuka değil, ayni zamanda insanlar arasında bulunması gerekli sevgi ve yardım duygularma da aykırıdır. Bundan bașka Luther, faizciliğin toplum düzeni bakımından da zararlı olduğunu belirtmekten geri kalmamıștır. (22)

Tanrı ve insan ilişkisini Luther'in yeni bir açıdan ele aldığı ve kilisenin aracılı̆̆ını ortadan kaldırmaya çalıştığı doğrudur. Onun savunduğu görüş̧ün normal neticesi, ferdin ayrı ve bağımsız bir değer olduğunun daha sonra benimsenmesi olmuștur. Yani Luther'in doktrini ferdiyetçilik akımının gelişiminde etkili olmuștur. Fromm, Luther'in kilise otoritesini reddetmesinin, inanç hayatunda insana ayrı bir yer vermesinin, ferdî sorumluluk duygusunun gelişmesi, vicdan hürriyetinin ve siyasî hürriyetlerin modern toplumda benimsenmesi bakımından olumlu etkiler yaptığını belirtmekte, ancak Luther'in öğretisinin ferdin toplumdan mânen ayrılması ve kuvvetsizleșmesi șeklinde olumsuz sonuçlar doğurduğınu da öne sürmektedir. (23)

Luther'in teorisinde Tanrmnı insanı çağırdığı iş veya meslek "beruf" terimi de yer almış bulunmaktadır. Luther, latinceden yaptı ̆̆ı dinî çevirilerde bu terimi kullandığı gibi, diğer bazı yazılarında da ayni terimden yararlanmıștır. (24) Manastırları tenkid eden ve manastırlarda yaşayan keşişlerin çalışmadan yaşamalarını dợ.

(21) Lelhmann, Paul Louis. The Standpoint of Reformation, Editor: Fletcher, Joseph F, Christianity and Property, Philadelphia 1947, p. 114.

(22) Lehmann, Paul Louis. op. cit., p. 117.

(23) Fromm, Erich, op. cit., p. 63.

(24) Fullerton, Kemper. Calvinism and Capitalism: An Explanation of the Weber Thesis, editor: Green, Robert W. Protestantism and Capitalism, Boston 1959, p. 9 . 
ru bulmadığını açıklayan Luther, katolik düșüncesinin israrla üzerinde durduğu asetizm prensibini kendi teorisine dahil edebilmek için, her insanın kendisini işine, mesleğine vermesini istemiş ve bu. nun Tanrı inayetine kavușmak için yararı bir araç olacağını sa. vunmuştur. Böylece katolikliğin yalnızca dinî bir zümreye tanıdığı asetizm'in daha geniş şekilde uygulanmasını; her insanın kendi. sini ișine vermek suretiyle sakin ve huzur dolu bir hayat yaşayabi. leceğini ve böyle bir yaşama yolunun din ilkelerine de uygun olacağın belirtmiştir. Ancak katolik felsefesinde, asetizm daha çok dinî bir mükellefiyet olarak belirdiği halde, Luther'in sisteminde, insanın kendisini dinî ibadete değil fakat dünyavî çalıșmaya vermek suretiyle Tanri'ya yaklaşabileceği belirtilmiştir. Max Weber, iş ya. hut meslek teriminin hem kelime olarak hem de kavram olarak Luther tarafından yepyeni bir anlamda kullanıldığını ve daha sonra da bu kavramın, özellikle Calvin'in öğretisi ışı̆̆ında modern kapitalist ruhunun doğumunda önemli bir rol oynadığını savunmuștur. (25) Ingiliz tarihçisi Robertson, Max Weber'in bu görüşünüi reddetmiş ve Luther'in iş veya meslek (beruf) kelimesine başka bir mana kazandırmadığını kelimenin Luther tarafından kullanılması ile kapitalist sistemin gelişmesi arasında herhangi bir ilişki aramanın yanlış olacağını öne sürmüştür. (26) Alman sosyoloğu Max Weber'in protestan reformu ve modern kapitalizmin gelişmesi hak. kındaki fikirleri üzerinde ilerde ayrıca duracağı.

\section{Calvin ve Özel Mülkiyet Sorunu}

Calvin, mülkiyet sorununu iki ayrı dönem bakımından ele alıp incelemiștir. Ilkel dönemde insanların mesut olduğunu, malların serbest şekilde el değiştirdiğini, insanların ya hibe veya hakkaniyete uygun bir değişme yoluyla ihtiyaç duydukları malları sağladıkla. rını ve bu sistemin bütün insanlara bolluk içinde yaşama şansını verdiğini kabul etmiștir. (27) Bu ilkel dönemin sona ermesi, ona göre, insanın ilk günahı işlemesi yüzünden olmuş ve ferdi mülkiyet hakkının uygulandığı yeni bir hayat safhası başlamıştır. Calvin, tabii hukukun degerini yitirdiği ve mukaddes kitap esaslarının uygulandı̆̆ı yeni đönemde mülkiyet sorunu üzerinde dururken, mül-

(25) Fullerton, Kemper, op. cit., p. 12.

(26) Robertson, H. M. A Criticism of Max Weber and His School, editor : Green Robert W. Protestantism and Capitalism, Boston 1959. pp. 68, 72.

(27) Biéler. André. La pensée économique et sociale de Calvin, Genève 1959. p. 345. 
kiyetin Tanri'ya ait olduğu yolundaki teolojik kanittan hareket etmektedir. Ancak ona göre, Tanrı, kendisine ait olan mülkiyet hak. kını, duyduğu sevgi dolayısıyla insana bağışlamıştır. Ferdi mülkiyet hakkına sahip olan insanın mülkiyeti yalnızca kendi menfaati için kullanmasını Calvin doğru bulmamaktadır. Malik olan kişiye yalnızca mânevî yönden Tanrıya karşı değil, maddi yönden de içinde bulunduğu topluma karşı bazı sorumluluklar yüklenmiştir. (28)

Calvin, mülkiyet hakkını bu şekilde sınırlamaya teşebbüs ettiği gibi, onun şarta bağlı bir hak niteliğini taşıdığını da belirtmektedir. Mülkiyet toplum yararına kullanılması gereken bir Tanrı hibesi olduğuna göre, mülkiyeti yalnızca kendj bencil amaçlanna göre kullananların ve halkı ezmek için mülkiyetin verdiği kuvvetten yararlananlarm, bu haklarından ilâhi şiddet yoluyla mahrum edileceklerine de Calvin inanmaktadır. Bundan başka Calvin, mülkiyetin şarta bağlı özelliğinden söz ederken, mülkiyet hakkının malike çalı̧̧ma borcunu da yüklediğini belirtmekte, malikin mülk sahibi olduğu için tembelliğe, israfa sapmamasının, aksine mülk konusu olan şeyi değerlendirmek maksadıyla çalıșmasının gerektiğini açıllamaktadır. Calvin'e göre «Tanrının kendisine verdiği malları ișlemeyen, Tanrı önünde suçludur.» (29); «insanlar tabiatı işlemek için yaratılmıșlardır.» (30)

«Hıristyan Dininin Kurumlar1» isimli eserinde Calvin, Luther gibi, on emrin "hirsızlık yapmayacaksm" ilkesinin mülkiyetin varlı̆̆ını gösteren sağlam bir teolojik kanıt olduğunu ileri sürmektedir. (31) Calvin, mülkiyet teorisini geliştirirken, orta çă̆ teologla. rının kullandıkları başka bir ilkeden, de yararlanmışıtır. Insanları, Tanrının yeryüzündeki vasalleri sayan teoriye göre, mü̈lkiyet malike sadece hak sağlamamakta, fakat fief mukavelesinde olduğu gibi bazı vecibeleri de yüklemektedir. Bu vecibeler arasinda mülkiyetin âdil şekilde kullanılması başta gelmektedir. Bundan, başka iyi niyetli mâlikin bu teoriye göre himayesi de kâbil bulunmaktadır. Diğer yandan Calvin, söz konusu teoriye dayanarak kilise mallarına el konulmasını da meşrulaştırmaya çalışmış ve günah yuvaları say. dığı manastır mallarına el konulmasının Tanrmon iradesine de uy. gun olacağını savunmuștur. (32)

(28) Biéler, André. op. cit., pp. 352, 353.

(29) Ibidem.

(30) Gagnebin, Charles. Calvin, Paris 1948 p. 195.

(31) Schlatter, Richard. op cit., p. 101.

(32) Schlatter, Richard. op. cit., p. 101, 102. 
Müilkiyet hakkının devlet iktidarı tarafından sınırlandırıması sorununda Calvin'in teorisi fazla açıklığa sahip bulunmamaktadır. Bunun sebebi, Calvin'in doktrinini, o devir Avrupasının siyasal bakımdan kararl ve ekonomik bakımdan kuvvetli olan Cenevre şehrinde açıklaması ve böyle bir problemle karşılaşmaması olabilir. (33) Ancak Calvin'in siyasal yöneticilerin ferdlerin mülkiyet alanına karışmamasını istediği söylenebilir. Siyasi otoritenin temel amacı herkesin rahatsız edilmeksizin mülkiyetten yararlanmasinı sağlamak olmalıdır. Prenslerin kamu yararı için vergi toplamaya hakları vardır. Bununla beraber kamu gelirini israf eden bir prens "müstebit» vasfını kazanır. Bütün bu fikirlerine rağmen Calvin, mülkiyet hakkına devlet yöneticilerinin saygı göstermemesi halinde ihtilâl yoluna başvurulması tavsiyesinde bulunmuş değildir. Diğer taraftan, Calvin'in devletin görevini, mülkiyetin hukuk yoluyla korunması olarak sınırlamadığını da belirtmek gerekir. Devlet yöneticisi, mülkiyetin semereleririn toplum yararına kullanılmasını sağlayacak tedbirleri almaya Calvin tarafından çağrılmaktadır. Ona göre, yöneticinin «ekonomik basireti, şereflilik kadar büyük bir fazilettir.» (34) Ekonomik hayata Calvin'in devlet müdahalesini istediğinin diğer bir kantt, Calvin'in yolundan yürüyenlerin Cenevre' de kurdukları yuiruitme organında-ki hem rahiplerden hem de rahip olmayanların kurulu idi - müşterisini aldatan tüccarı, idarenin tesbit ettił̆i fiyatın üstünde satıs yapan kasabı, yabancıya yüksek fiyatla elbise diken terziyi, ameliyat için yüksek para isteyen cerrahı cezalandırmalaridır. (35)

Calvin faiz konusunda hem Luther'den hem de orta çağ teolojisinden kısmen farklı bir yol takib etmiştir. Onun düşüncesine göre, fakir bir insanın faiz yoluyla sömürülmesi ahlâk ve adalet ilkelerine aykırıdır. Bu yüzden faizle ödünç para veren kişinin ve eşinin bazı dinî âyinlere kabul edilmemesini Calvin uygun görmüștü. Bununla beraber amacinın faizle para verilmesini tamamen orta. dan kaldırmak veya faiz kurumunu yok etmek olmadığın belirtmekten de geri kalmamıştı. Zengin bir tacirin ișini ilerletmek için faizle ödünç para almasını Calvin meșru karşılıyor ve böyle birine borç vereni de ayıplamıyordu. Calvin'in faizle ilgili sınırlı yasağı Calvinist liderlerden birisi olan Claudius Salmasius'un 1638 yllında yazdı̆̆ Faiz Hakkında (De Usuris) isimli eserinden sonra daha da

(33) Fromm, Erich. op. cit., p. 74.

(34) Biéler, André, op. cit., p. 383.

(35) Tawney, R. H. op. cit., p. 117. 
yunuușatılmış ve bir süre sonra da önemini tamamen kaybetmiş• tir. (36)

Ahlâk sistemi bakımından Calvin'in en önemli özelliği ilâhi takdir (predestination) üzerinde israrla durmasından doğmaktadır. Onun kanaatine göre, Tanrı bazı insanları ebedi lânete mahkûm etmiștir. Bazı insanlar ise doğuşlarından Tanrının bağışlamasına sahip bulunurlar. Böylece Calvin, St. Augustine'ninkine benzeyen bir görüșü savunmuş olmaktadır. Bazı insanların hayır için, diğer bazılarının şer için seçilmesinin sebebini insan akh açıklayamaz. $\mathrm{Bu}$ kaderi insanların ne kadar çaba gösterirlerse göstersinler değiştirmelerine de imkân yoktur. Bunun içindir ki, Fromm, Calvin'in tasavvur ettiği Tanrının, sevgi ve adalet kavramlarını ona mal ctmeye çalışmasına rağmen, esas itibariyle sevgi ve adalete sahip bulunmayan bir «zalim» olduğunu ifade etmektedir. (37)

Calvin'in ilâhi takdir teorisinin konumuz bakımından önemi bu teori dolayısıyla çalıșmaya verdiği değerden ileri gelmektedir. Calvin, insanların kurtuluşa (salvation) erişmesinin kendi ellerinde olmadığını söylemekle beraber, devamlı şekilde çalıșmayı ve faaliyette bulunmayı onlara tavsiye etmeye özellikle dikkat etmiștir. Calvin'in tavsiye ettiği faaliyet muhtemelen ahlâki faaliyet olmuş. tur. Ancak Calvin teorisindeki çalışma unsuru daha çok dünyevî faaliyet olarak yorumlanmış ve anlaşılmıștır. Bu konuda Calvin'in «Tanıı kendi inayetinin çalışanların elleri üzerinde olacağına söz vermiştir.» (38) ve "hayatlarını tembellikle geçirenler için özür bulunmayacaktır.» (39) gibi açıklamalar yaptığını ve çahışmayı muhtelif fırsatlardan yararlanarak daima teșvik ettiğini belirtebiliriz. Clavier, Calvin'in çalıșmaya Luther'den de fazla önem verdiği. ni söylemektedir. (40)

Çalışmanın değeri üzerinde dururken Calvin, ilâhi takdir ilkesinden vazgeçmemektedir. İnsanlar kendileri için mukadder olan hayat ${ }_{1}$ yaşamak zorundadırlar. Bununla beraber Calvin insanın çalıșmasını, çaba göstermesini, kurtuluşa (salvation) erișmenin bir ișareti olarak değerlendirmeye de temayül etmiștir. Gerçekte,

(36) Bu konuda bk. Weber, Max. General Economic Theory, Ingilizceye çeviren : Knight, Frank H. 1930, p. 271.

(37) Fromm, Erich. op. cit., p. 75.

(38) Gagnebin, Charles. op. cit., p. 194.

(39) Bagi, Louis. La garantie constitutionnelle de la propriété, Lausanne 1956, p. 49 , n. 128.

(40) Clavier, H. Le Christianisme et le travail, 1944, p. 75 . 
insan kendi geleceğinin ne olacağı, kurtuluşa erişip erişemiyeceği șüphesi içinde yaşar. Bu şüpheyi yenmenin, geleceğe ümitle bak. manın en iyi yolu insanın kendisini çalışmaya vermesidir. Insanın çalışma yoluyla kaderini değiştiremiyeceği bir gerçek olmakla beraber, çalışma yoluyla kazandığı başarı, ebedi imtihanında onu teselli eden, ve belki de Tanrı sevgisinin kendisiyle beraber olduğunu gösteren değerli bir işarettir.

Orta çă̆ düșüncesinden ve kısmen de Luther'den Calvin'i ayıran diğer bir özellik, onun ticari faaliyeti olumlu saymasında belirmektedir. Orta çă̆da, toprak geliri fazla tartışma konusu yapılmamış ve bu gelirin normal ve meşru nitelik taşıdığına inanılmıştır. Buna karşı hıristyan dini, ticari faaliyetlere çoğu zaman şüphe. li gözle bakmıştır. Ayni görüș Luther'in fikirlerini de etkilemiștir. Calvin, muhtemelen Cenevre gibi ticari bir şehirde yaşadığı ve öğ. retisini benimseyenler arasında tüccarlar aktif bir grup olarak belirdikleri için, ticari faaliyeti olumlu ve faydalı karșılamak yolunu tutmuştur. Onun bu konudaki açıklamaları, ticari faaliyeti yararlı saydığinı ve ticaret yoluyla elde edilen kazancı meșru olarak nitelendirdiğini ifade etmektedir. Calvin «iş adamının kazancının top. rak sahibinin kazancından daha fazla olmaması için bir sebeb var mıdır?... Tüccarın kazancı da yalnızca onun sebat ve çahşkanlığın+ dan gelmez mi?" diyerek ticari faaliyet ve kazancı meşrulaștırmiştır. (41)

Kalvinizm'in, Anabapistlere ve diğer aşırılara karşı tutumu Luthercilerinkine benzemektedir. Calvin de, Luther gibi ortak muilkiyet uygulamasını reddetmiş, orta sinffın, temayiillerine uygun bir dokrinin savunmasını yapmıștır. Tawney'e göre, kalvinizm ilk hlristyanlık ve modern sosyalizm gibi bir şehir hareketi niteliği taşımıştır. Bu akımın memleketten memlekete yaylmasında tüccarlar ve işçiler önemli bir fonksiyon ifa etmişlerdir. (42) Ancak Calvin'in kendi doktrinini yaydığı sırada uğraştı̆̆ı problemler, Luther'inkiler kadar çok olmamıştır. Bundan başka Calvin'in sisteminde, çiftçi ve köylü sorunları fazla önemli bir yer işgal etmemiştir.

Luther'in öğretisi Avrupada büyük yankılar uyandırdı̈̆ halde Calvin'in fikirleri Anglo - Sakson ialkelerinde daha etkili olmustur. Özellikle İngilterede beliren puritanizm hareketi Calvin ögre. tisinin Anglo-Sakson memleketlerindeki vârisi sayılmıștır. Ingil-

(41) Tawney, R. H. op. cit., p. 105.

(42) Ibidem. 
terede XVI. yüzyllın ikinci yarısında ortaya çıkan, orta sınıf arasında taraftarlara sahip bulunan puritanizm, ferdin değeri ve önemi üzerinde durmuş, doğruluğa ve çalışmaya dayanan bir hayat yolunun dine uygunluğunu belirtmiş, hem dinî, hem siyasî alanda hertürlü despotizme karşı çıkmıștır. Puritanizmin etkisi yalnızca İngiltere'de kalmamıs, özellikle XVII. yüzyılda Kuzey Amerika'ya yerleşen puritanlar, Yeni İngilterede kendi doktrinlerini uygulamak için elverişli bir ortama sahip olmuşlardır. Yeni İngilterede puritanların kurdukları toplumda, devlet ve kilise üyeliği ayni șahısta birleşmiș, diğer dinî göriișlere hoşgörü göstermeyen bir sistem uygulanmıştır. Ancak zamanla yapılan dinî smırlamalar önemini kay. betmiş ve diğer mezheplerden olanlara vicdan ve ibadet hürriyeti tanınmıștir.

Calvin'in mülkiyet teorisi, şimdiye kadar verdiğimiz izahattan da anlaşılacağı gibi, mülkiyeti mutlak bir hak saymamış, hele bu hakkı tabii hukuk yoluyla meşrulaştırmak teşebbüsünde bulun. maktan dikkatle kaçınmıștır. Ancak Calvin insanlar arasında sosyal ve ekonomik ilişkilerin sükünet ve adalet içinde yürümesi bakımından, özel mülkiyetin yararlı ve lüzumlu bir kurum olduğunu kabul etmiștir. Toplum hayatında iktisadì ahengin gerçekleşmesi bakımından devletin muidahalesini ve iktisaden zayıf olanların kuvvetli olanlara karşı korunmasın kalvinizmin desteklediği söylenebilir. (43) Diğer taraftan Calvin'in ticari ve iktisadi faaliyetlerde daha az sınırlı bir hürriyet görüşünü desteklediği, faiz kurumunu diğer orta çag teologlarından ve Luther'den daha farklı șekilde ve oldukça geniş̧ bir hoşgörü ile karşıladığı ayrıca belirtilebilir. Calvin doktrinin en ilginç özelliklerinden birisi, çalışmayı dinî sebebler dolayısıyla da olsa daima teşvik etmesi olmuștur.

\section{v. Reform Hareketi ve Kapitalizm}

Alman sosyoloğu Max Weber'in 1904 - 1905 yıllarında ve 1906 yllında yazdı̆̆ı makalelerde öne sürdü̆gü, modern kapitalizmin doğuşunda ve gelișmesinde protestanlığın etkili bir rol oynadığı gö-

(43) Biéler, André. op. cit., pp. 389, 390, Biéler, Calvin'in ekonomik ve sosyal fikirleri konusunda yaptığ endüstri kapitalizminin ortaya çıkmasında bir rolü olmadığını, aksine Calvin'in paranın tahakküm edici bir güç haline gelmesini ve, fakirlerin zenginler tarafından ezilmesini reddettiŏini; devletin âdil ve dengeli bir ekonomik düzen kurmak için müdahale etmesini istediğini savunmaktadır. Sözü geçen görüşlerin tenkidi için Bergier'in Annales économies, sociétés, civilisations No. 2 Mars, Avril 1962 de çıkan makalesine bakiniz. 
rüşü uzun tartışmaların yapılmasına sebeb olmuștur. Makalelerden birisi Protestan Ahlâkı ve Kapitalizm Ruhu (Die protestantische Ethik und der Geist des Kapitalismus), diğeri ise Protestan Mezhepleri ve Kapitalizm Ruhu (Die protestantische Sekten und der Geist des Kapitalismus) başlı̆̆ını taşımışıır. Düşüunürler bu konuda Weber'in tezini kabul edenler ve reddedenler olmak üzere âdeta iki ayrı kampa ayrulmışlardır. Weber'in tezini açılamasından sonra sözü geçen sorunla ilgili olarak yapılan araştırmalar özellikle Reform devresi Avrupa toplumunun sosyal ve ekonomik bünyesinin daha iyi incelenmesi ve anlaşılması hususunda yardımcı olmuştur. Bununla beraber tartışmanın tazeliğini ve canlılığını halâ muhafaza ettiğini bu fursattan yararlanarak belirtmek gerekir. Reform hareketinin, modern kapitalizmin doguş̧unda ve gelișmesinde etkisi olup olmadığı, eğer olmuşsa bu etkinin derecesinin tesbiti, inceleme konumuzla doğrudan doğruya ilgili değildir. Zaten Max Weber' in ileri sürdüğü tez, protestanlığın mülkiyet görüşünün kapitalizmin doğumunda tayin edici bir rol oynadığ tadır. Bununla beraber reform öğretisinin yeni bir toplum düzeninin doğușunda nasıl bir etkide bulunduğu sorunu araștırılmadan Luther ve Calvin'in sosyal ve ekonomik görïşlerinin gerektiği șekilde değerlendirildiği de söylenemez. Bu sebebten sözü geçen prob. lem üzerinde kısaca olsa bile durmakta fayda vardır.

Max Weber, ilk önce kapitalizm deyimini incelemiștir. Ona göre, elde etme ve kazanma saikinin, mümkün olduğu kadar çok paraya sahip olma amacının, kapitalizmle doğrudan doğruya hiçbir ilişkisi yoktur. Bu saik garsonlar, doktorlar, arabacılar, artistler, rüşvetçi memurlar, kumarbazlar ve dilencilerde de bulunabilir. Kazanma saikinin, bütün zamanlarda ve bütün memleketlerde objektif bir imkân var olduğu takdirde, bütün insanlar arasında ortak olduğu söylenebilir. Sınırsız kazanç hırsı kapitalizmle ayni şey değildir, bu hırsın kapitalizm ruhu ile ilișkisi ise çok daha azdır. Buna karşı kapitalizmin, itidal ile hiç olmazsa, gayri akli ka. zanç saikinin akıl yoluyla hafifletilmesiyle ayni şey olduğu ileri sürülebilir. Ançak kapitalizmin, kazanç peşinde koşmakla, devamlı, aklî, kapitalist teşebbüs aracılı̆̆ı ile daima yenilenen şekilde ka. zanç peşinde koşmakla ayni şey olduğu ifade edilebilir. Bunun böyle olması da lâzımdır. Çünkü tamamen kapitalist bir toplum düzeninde, kâr elde etmek hususundaki firsatlardan yararlanmayan bir kapitalist teşebbüs, yok olmaya mahkumdur.

Max Weber'e göre alacaklı ve borçlu sinfflar toprak sahipleri ile topraksızlar yani, serfler veya kiracilar; üreticiler ve tüketiciler 
arasında çatışmalar değişik şekillerde heryerde dikkati çekmiş. tir. Bununla beraber, batıda görülen büyük endüstri müteşebbisi ile ücretli hür iş̧̧i arasındaki çatışma tamamen modern ve evvelce var olan çaıışmalardan farkhı bir nitelik taşımaktadır.

Kapitalizm, mübadele temeline dayanmakta ve iki smifın faaliyeti bu sistemde görülmektedir. Üretim araçlarına sahip bulu. nanlar kapitalist sisteminin süjeleridir. Bir de mülkiyet hakkından yararlanmayan iş̧̧iler vardır ki, bunlar da sistemin objeleridir Kapitalizm, kazanç arzusu ve ekonomik rasyonalizm tarafından idare edilir.

Teknik imkanların gelişmesi batı tipi kapitalizme geniş ölçïde etki yapmıștır. Ancak batı kapitalizmi sadece teknik istihsal araçlarına değil, fakat belli bir hukuk sistemine de ihtiyaç duyar. Modern rasyonel kapitalizm, yalmızca teknik üretim araçlarma değil ayni zamanda güvenilir bir hukuk sistemine ve şeklî kaide. lere dayanan bir idare sistemine de sahip olmalıdır. Böyle bir hu. kuk düzeni olmaksızın cüretli veya karaborsacı kapitalizm müm. kün olabilir. Fakat ferdi teșebbüs fikrine bağlı, belli bir kapitale ve belirli hesaplara dayanan rasyonal kapitalizm, mevcut olamaz. Modern kapitalizme elverişli bir hukuk ve ekonomi sistemi ise an. cak batıda görülmüștiir. Bu hukukun nereden geldiği sorunu üze. rinde duran Max Weber, kapitalist çıkarlarn böyle bir hukuk diizeninin kurulmasında kendilerine düșen fonksiyonu ifa ettiklerini, ancak bu çıarların kendiliklerinden hukuku yaratmalarına imkân olmadığını ifade etmektedir. (44) Tamamen başka nitelik taşıyan kuvvetlerin bu gelişmede rol oynamıs bulunması lâzımdır. Bu gelişmeyi sağlayan kuvvetler üzerinde yapllacak bir inceleme bizi, batı kültürünün rasyonalizmi sorununa götürür. İktisadi rasyonalizmin gelişmesi, rasyonel ekonomi tekniğine ve hukuka bağlı ol. makla beraber, insanların belli pratik davranma sekillerine kendi. lerini uydurma temayül ve kabiliyetleri de bunda rol oynar, Büyü ve din kuvvetinin ve bunlara dayanan ahlâki ödev fikrinin insan davranıșlarmın şekillenmesinde daima önemli bir rolü olmuş̧tur. Her din sosyal ve iktisadi bir ahlâk görüșünü geliştirir. Dinlerde saklı bulunan sosyal ve ekonomik ahlâk insanların sosyal hareketlelerini kuvvetle tesir altında birakmakla kalmaz, ayni zamanda top. lum düzeninin objektif bünyesi esasların tayinde de rol oynar.

(44) Weber, Max. The Auhor Defines His Purpose, editor: Green, Robert W. Protestantism and Capitalism, Boston 1959, p. 5. 
Modern kapitalizm ruhunun ne olduğu Max Weber'in asıl anlamak ve açıklamak istediği sorundur. Ona göre, modern kapita. lizmin bașlıca özelliği, psikolojiktir, diğer bir deyimle para kazanma özelliği modern kapitalizmin ayırıcı psikolojik unsurudur.

Burjuvazinin büyiik ticaret sınıfları başlıca protestanlar arasında dikkati çekmektedir. Belli başl müteşebbislerin, tüccarların, sermayedarların, teknik uzmanların sayısı protestanlar arasında katoliklere oranla daha fazladır. Ispanyollar bunu çok önceden görmüşler ve Hollanda kalvinizmini kastederek dalâletin ticareti ilerlettiğini söylemişlerdir. (45) Modern anlamda kapitalizmin gelişmesi, dikkati çekici ölçüde, protestanlığın Lutherciliğe aykırı asetik (ascetic) șeklinin yayılması IIe ayni zamanda olmuștur. Weber, bunun basit bir tesadüf olmadığı, kapitalist ruhun belirmesi ile Kalvinist teolojinin hâkimiyeti altında bulunan protestanlığın asetik șeklinin gelișmesi arasında organik bir ilișkinin bulunduğu fikrindedir.

Bir insanın bütün kabiliyeti ve enerjisi jle para kazanmasının gerekli olduğunu Benjamin Franklin'in Genç Bir Tüccar'a Ögüt'ünde (Advice to a Young Tradesman) açıkladığına Max Weber ișaret ediyor. Benjamin Franklin'e göre para ihtiyaçları karşlamak veya gelecekte harcanmak üzere kazanlmamalıdır. Aksine para kazanma başlı başına bir amaç olmalıdır. Başka deyimle, para kazanmak için, para kazanılmalıdır. Franklin'in üzerinde durduğu nokta, para sevgisi değil, para kazanma zorunluluğudur. Kendi tezini doğrulamak için Franklin, Tevrat'tan da iktibasta bulunmakta ve Süleyman'm Meselleri Kitabında yer alan «Ișinde gayretli adamı görüyor musun? O kıralların önünde durabilir.» sözïnü belirtmektedir. Weber, para sevgisinin değil, para kazanma zorunluluğunun Franklin'in ögretisinde başlıca rolü oynadı̆̆ını ve modern kapitalizm ile geçmiş zamanlardaki kapitalizm şekilleri arasındaki temel farklılığın para kazanma zorunluluğunun insanlara aşılanmasında belirdigini ifade ediyor. (46)

Max Weber kapitalizm öncesi ekonomi şekillerinde, işçinin de iş verenin de gelenekçiliğin (traditionalism) etkisi altında para'ya karșı belli bir kayıtsızlık gösterdiğini, kapitalizmden sonra, daha fazla para kazanmaya karşı olan ilgisizliğin müteşebbisler ara-

(45) Fullerton, Kemper, Calvinism and Capitalism: an Explanation of the Weber Thesis, editor: Green, Robert W. Boston 1959, p. 7.

(46) Fullerton, Kemper, op. cit., p. 8. 
sında kaybolduğunu, fakat işçiler arasında devam ettiğini söylüyor.

Bununla beraber modern kapitalizm ruhunun, para kazanmayı, bașlı bașına bir amaç sayması yanında, ikinci bir özelliği daha vardır. Modern iș hayatında devaml bașan gösteren müteșebbisler yahızıca kazanç uğruna kazanç amacını gütmemekte, bunun yanında kendi kendini disiplin altına alma veya asetizm de onların hayatında dikkati çekmektedir. Bu insanlarda israf temayülui, gösteriş arzusu bulunmamaktadır. $O$ halde kapitalizm ruhunun ikinci özelliği, gösteriş ve israfa kaçmayan, disiplinli ve asetik bir hayat tarzı olarak tesbit edilebilir. Acaba söz konusu bu disiplinin amacı nedir? Weber bu feragatin gayesinin gittikçe daha fazla kazanmak olduğunu belirtmektedir.

Weber için önemli olan kapitalizm ruhu'dur. Genel olarak kapitalist ekonomi șekilleri ile kapitalist ruh bir arada görünür. Fakat bunun böyle olmadığı zamanlar da olabilir. Kapitalist ruh, yani bir insanın kendi mesleğine ve işine bağllı̆ğı XVII. yüzyılda puritanların hâkim bulunduğu Amerikadaki Yeni İngilterede dikkati çekiyordu. Bununla beraber Yeni Ingilterede gelișmiș bir eko. nomi hayatı mevcut bulunmuyordu. Ekonomik yönden çok daha gelişmiş olan Amerikanın güney devletlerinde ise, kapitalist ruhun bu dönemde bulunmadığına Max Weber dikkati çekmektedir. Gene XIV. ve XV. yüzyıllarda katolik Floransada kapitalist ekonomi șekilleri var olduğu halde kapitalist ruhun mevcudiyetinden söz edilmesine imkân yoktur. (47)

Kapitalist ruh ile protestan ahlâkı arasında bir ilişkinin bulunduğuna inanan Weber, din tarihi ile ilgili bazı arasstırmalar yaparak, daha önce söz konusu ettiğimiz Luther'in öğretisindeki beruf kelimesinin. protestan reformcu tarafindan o zamana kadar kullanılandan farklı bir anlamda kullanıldığına ișaret ediyor. Weber'e göre, ne antik felsefe, ne de katoliklik is veva meslek terimini. Luther'in anladığı manada değerlendirmiș değildir. Luther, günlük çalışmanın Tanrı tarafından emredilen bir ödev olduğunda israr etmis ve beruf kelimesine bambaşka ve dünyevî bir anlam kazandırmıștır. Ancak, Luther, para kazanmaya karșı olan tutumu bakımından bir gelenekçi olarak kalmış ve modern kapitalizm ruhunu yansitamamıștır.

(47) Fullerton, Kemper, op. cit., p. 9. 
Calvin, ögretisinin, modern kapitalizm ruhunun belirmesinde çok önemli bir fonksiyon ifa ettiğine, Weber inanyyor. Hiristiyan dinini Roma Kilisesine karşı açıklarken Calvin, Tanrı kavramın. dan hareket etmiştir. Tanrının mutlak bir irade, mükemmel şekilde hür tek varlık olduğunu belirtmiş, yani Tanrı iradesinin onu ister anlayalım, ister anlamayalım, doğru olduğunu veya öyle kabul edilmesini gerektiǧini söylemiştir. Weber'e göre, Calvin aklî olmayan bir Tanrı kavramından başlamakta, daha sonra bu kavramı aklîleştirmeye gayret etmektedir. Insan aklını, Tanrı idealinden uzaklaştıracak herşey reddedilmelidir. Insan faaliyetinin Tanryya yönelmesi ancak disiplinli ve münzevi bir yaşama şeklinin benimsenmesiyle mümkün olabilir. Bu sebebtendir ki, asetizm kalvinizmin ve daha sonraki puritan hareketinin önemli bir özelliği olmuştur.

Bundanbaşka Weber, daha önce üzerinde durduğumuz ilâhî takdir (predestínation) sorununa değinmekte, Calvin'in katolikliğin itiraf metodunu reddettiğini; dolayısıyla insanın din̂̂ kurtuluşu (salvation) için uygulanacak iki yol kaldığını; bunlardan birisinin insanm Tanrı kuvvetinin kendisiyle beraber olduğu hususunda derin bir inanca sahip olması, diğerinin ise devamlı şekilde çalış $t_{\imath}$ ğı ve başardığı takdirde Tanrı iradesinin kendi yanında bulunacağının insana öğretilmesi olduğunu açıklamaktadır. Calvin, birinci yolu tercih etmiş ve buna teolojisinde önemli bir yer vermiștir. Ancak ikinci yol, uygulamada gittikçe artan bir önem kazanmıştır.

Weber'e göre, Calvin Tanrı ve insan arasında kilisenin aracilğmı reddettiği için Luther gibi ferdiyetçidir. Çünkü ferdin ayrı ve bağımsız bir değer olduğunu kabul etmiștir. Ancak kalvinizm aşırı ferdiyetçiliğin yanında yoğun sosyal çalışmayı da desteklemiş ve bu yönden Lutherci protestanlıktan ayrılmıştır. (48)

o halde kalvinizm, bir yandan insanın devamlı şekilde işiyle uğrașması ve başarı kazanması, öte yandan da, disiplinli ve münzevi bir hayat yaşaması üzerinde israrla durmuştur.

Puritanizm, Calvin'in ögretisini pragmatik anlamda daha da ileriye götürmüştür. Herkesin işine en büyük ilgiyi göstermesi prensipi, disiplinli ve asetik hayat görüşüi ile birleștirilmiş, çalışma takdir edilirken israf yerilmiştir. Puritanlar, feodal aristokrasinin yașama yolunu tenkid etmişler, tüketimin mümkün olduğu kadar

(48) Fullerton, Kemper. op. cit., p. 11. 
az olmasımı, fakat çalışma ve üretimin daima çoğaltılmasını istemişlerdir. (49)

Tüketimin dikkatle sınırlanması, üretimin metodlu şekilde artırlması, sermayenin toplanması neticesini doğurmuștur. Böylece, zenginliğin insan ahlâkın bozucu etkisi ile ilgili puritan öğretisi gittikçe önemini kaybetmiştir.

Başlangıçta çalışmanın insanın kurtuluşunu (salvation) sağlayan bir araç olduğu savunulduğu halde, kapitalizmin gelișmesiyle beraber, para kazanmak, Benjamin Franklin'in belirttiği gibi başlı başına bir amaç haline gelmiștir. Soyut iş veya meslek fikri, Tan. ronm her insan için tayin ettiği iş veya faaliyet kavrammın yerini almıștrr.

Max Weber'in teorisi karșı ve yana çeșitli görüşleri davet etmiş ve cnine boyuna tartışılmış̣tır. Weber, tezini açıklarken, modern kapitalizmin gelișmesinde «kapitalizm ruhu»nun önemli bir rol oynadığım savunan Werner Sombart'in görüșlerinden yararlandığmı belirtmiștir. Bununla beraber Werner Sombart, daha sonra kapitalizmin protestanlıktan daha önce doğduğunu beyan ederek, Weber'i tenkid eden Alman düsünürü $F$. Rachfall'nn fikirlerine katıldığını açıklamıștur. Sombart'a göre, puritanizm olsa olsa perakendecilikle uğraşan küçük tüccarnn faaliyetini teşvik etmiş sayılabilir. Puritanlar arasında büyük bazı kapitalist müteșebbisler bulunmuștur. Ancak bunların bașarılarında puritan ahlâk görüșünün rol oynayıp oynamadığı şüphelidir. Bununla beraber kabul etmek gerekir ki, Weber'in tezini en kuvvetli șekilde tenkid eden fikir adamı Ingiliz tarihçisi Robertson olmuștur.

Robertson, Weber'in kapitalizmin gelișmesi problemini tarihî değil, sosyolojik açıdan incelemesinin yanlıs olduğunu ifade etmekte, «kapitalizm ruhu" nun dinî saiklerin değil, fakat medeniyetin maddi șartlarmdaki gelişmenin sonucu olduğunu söylemektedir. (50)

Luther, «beruf» kelimesini, Robertson'a göre yeni bir anlamda kullanmıș değildir. Herkesin Tanrı tarafından kendisi için tayin edilen işle uğraşması ilkesinin çok eski bir geçmișe dayandığını St. Paul'un "çalışmayanın, yemeye de hakkı olmadığını size emret-

(49) Fullerton, Kemper. op. cit., p. 18.

(50) Robertson, H. M. A Criticism of Max Weber and His School, editor: Green, Robert W. Protestantism and Capitalism, Boston 1959. p. 67. 
tik» dediğini Robertson ayrıca ileri sürüyor. Herkesin Tanrı tarafından çağırıldığı işi yapması fikrinin ilâhi ve tabii dağıtıcı adalet (distributive justice) görüşüüun normal sonucu olduğunu ve bu konuda katolikJik ve punitanizm arasmda herhangi temel ayrilık ofmadığını açıklıyor. (51) Bir insanın kendisi için tayin edilen işi yapması fikrinin aç gözlï ihtirasa karşı bir panzehir olarak düşüinüldüğ̈unü, fakat daha sonra bu fiknin anlamını değiştirerek, ticari bir halkın çıkarına elverișli bir doktrin yarattığını ve bu gelişmede bizzat kapitalizmin etkili olduğunu belirtiyor.

Ferdiyetçilik, temel olarak serbest ticaret, rekabet ve mülkiyet sistemidir. Ferdi ve ferdî kabiliyeti, sosyal organizasyonun esası sayar. Orta çağda yalnızca mülkiyet hakkı tanınmıs, serbest ticaret ve rekabet ilkeleri reddedilmiști. Diğer taraftan orta çağın mülkiyet anlayışı da modern mülkiyet anlayıșından farklıydı. Bununla beraber kapitalizm, genel şekilde uygulanmadığı orta çağın sonunda biliniyordu. Bu sebebten ona reformun bir sonucu gözüyle bakmak doğru değildir. Çünkü kapitalizmin özellikleri orta çağ sonunda mevcut bulunuyordu.

Orta çă̆ kilisesi, farklı sınıflara mensup insanlara karşı olan ödevini biliyordu. Başlıca iki sınıf vardı. Bir tarafta zenginler ve büyükler, diğer tarafta fakirler ve sefiller. Bu basit sınıf ayrımı değersiz hale geldiği zaman kilise yeni bazı problemlerle karşılaştı. Bu yeni problemler önem kazanmaya başladığı sırada St. Thomas Aquinas oldukça isteksiz şekilde tüccarların faaliyetini meşru gös. teren yazilar yazmak zorunda kaldı. St. Antonio da XIV. yüzyıl Floransasında benzer ve daha önemli sorunlarla ugraşmak zorunluluğunu duydu. XVI. yüzyılda bütün kiliseler ekonomik dïzendeki değişmenin doğurduğu problemlerle karşılaștılar. Robertson'a göre, bütün bu örnekler, kapitalist gelişme ile protestanlık arasında bir ilişki bulunmadığını göstermektedir. (52)

Zaten kapitalizm ruhunu doğuran en önemli sebeb kapitalizmin kendisi olmuştur. Bu gelişme genel kültür şartlarındaki, özellikle ekonomi tekniğindeki değişmenin sonucu olmuş, siyasi ve hukukî kurumlar da söz konusu değișmeyi etkilemiștir. (53)

Burjuva liberalizminin zaferini sağlayan belli bașlı faktör, burjuvaziyi önemli kılan ekonomik gelişme olmuştur. $\mathrm{Bu}$ arada

(51) Robertson, H. M. op. cit., p. 69.

(52) Robertson, H. M. op. cit., p. 83.

(53) Robertson, H. M. op. cit., p. 81. 
Robertson İngiltere'de burjuva ahlâkının dinin yerini almasının puritanizmle ilgili olmadığın da belirtmektedir. (54)

Robertson'un vardığı sonuç, kapitalizmin maddi şartlardaki değişmenin bir sonucu olduğu ve protestanlıkla, özellikle kalvinizmle bu gelişme arasında herhangi bir ilişki olmadığ yolundadır. Robertson, Weber'in teorisinin, ekonomi tarihinin önemli bir sorunu hakkında, modern düşünceye yanlış bir istikamet verdiğini ve amacının bu yanlışlı̆̆ı düzeltmek olduğunu açıklamaktadır.

Italyan politikacısı ve iktisatcısı, Amintore Fanfani de sözü geçen tartışmaya katılmıştır. Fanfani genel olarak Robertson'un görüşlerini paylaşmakla beraber bazı noktalarda ondan ayrılmaktadir.

Fanfani, protestan ihtilâlinden önce Avrupa'nın kapitalizmle karş̧laştığını, reformdan bir asır önce kapitalizmin gittikçe büyüyen etkili bir kuvvet niteliğini taşıdığını, yalnızca kişilerin değil fakat. ayni zamanda sosyal grupların da yeni bir ruhla dolu olarak henüz kapitalizmi kavramamış olan orta çağ toplumu ile savaştıklarını ifade etmektedir. Bu sebebten Fanfani, Robertson'un savunduğu, protestanlığın kapitalizmi değil, fakat kapitalizmin protestanlığı etkilediği görüşuinüi benimsiyor. (55)

Insan, Fanfani'ye göre kazanç içgüdüsü ile doğar. Diş kuvvetler bu içgüdüyü yá engellerler veya teșvik ederler. İște bu içgüdü kapitalizmin özüdür. Bu anlamda kapitalist ruh her zaman var olmuştur ve her zaman var olmaya devam edecektir. Ancak sosyal bir kuvvet olarak kapitalist ruhun her zaman mevcut bulunduğu söyle. nemez.

Ekonomik alanda yeni bir görüşün yaratılması, protestanlığın işi olarak vasiflandırılamaz veya herhangi bir protestan mezhebine mal edilemez. Bu yeni görüș, rönesans ve reformu belirten bir diişünce devriminin sonucudur ve, sanata, felsefeye, dine, ahlâka, ve ekonomiye orta çağda konulan sinırlamalardan ferdin kurtulma çabasını ifade etmiş̧tir. Protestanlık, dünyevî çalıșma inancını insanlara aşılamak yoluyla kapitalist ruhun hâkimiyetini kolaylaşturmıș veya onu meşrulaştırmıș ve kutsallaştırmıştır. (56)

(54) Robertson, H. M. op. cit., p. 85.

(55) Fanfani, Amintore. Catholicism, Protestantism and Capitalism, Editor: Green, Robert W. Protestantism and Capitalism, Boston 1959, pp. $87,90$.

(56) Fanfani, Amintore. op. cit., p. 93. 
Kısaca belirtmek gerekirse, Fanfani, kapitalizmin, hiç olmazsa onun görülebilir işaretlerinin, reformdan önce var olduğunu kabul etmekte, ancak kapitalist sistemin gelişmesinde protestan ahlâk anlayıșını, kolaylaştırıcı, yardım edici bir rol oynadığını söylemektedir.

Bu konudaki tartışma bütün canlılı̆̆ı ile devam etmektedir. Şüphesiz tartışmaya katılan fikir adamlarının kenđi dinî inançlarının az veya çok etkisi altında kalmaları, sorunla ilgili kanıtların bazan Weber'in tezi için, bazan da onun tezine karşı değerlendirilmesine sebeb olmaktadir.

\section{Sonuç}

XVI. yüzyll reform hareketi, bütün Avrupayı sarsan sosyal ve ekonomik bir değişmeyle beraber belirmiștir. Orta çağ feodal düzeninin yıkılmaya başladığı, ticaret hayatının geliştiği ve ticaret loncalarının kapitalist ticaret önünde önemini yitirdiği, senyör ve vasal anlaşmasına dayanan ve serflik kurumu ile beslenen ekonomik ilişkilerin yeni bir yön kazandığı, merkezi siyasi iktidarın kuvvetlendiği bir dönemde, katolik kilisesinin haksız servetine, din üzerindeki tekelciliğine bir baş kaldırma niteliğini taşıyan reform hareketi, kültür hayatını boyunduruktan kurtarmak amacını güden rönesans akımının din alanında bir devam olmuştur.

Bundan önceki bölümlerde, reform akımının iki ünlü adamı, Luther'in ve Calvin'in mülkiyet konusundaki fikirleri, enine boyuna tartışılmış, ayrıca onların mülkiyet görüşüi ile orta çă̆ mülkiyet anlayışı arasındaki ayrılıklar üzerinde durulmuştur. Mülkiyet konusunda ne Luther'in, ne de Calvin'in, hrristyan mülkiyet kavramtnı kendi zamanlarının sorunları ile uzlaştırmaktan öteye geçen bir katkıları olmadığı söylenebilir. Gene onların, St. Thomas Aquinas gibi sistemli bir mülkiyet teorisi kuramadikları da belirtilebilir.

Her çağ sosyal ve ekonomik hayata ait teorisini yaratır ve değişen ihtiyaçlara göre bu teoriyi düzeltir, tekrar düzeltir ve geliştirir. Orta çağ insanımın problemleri, reform döneminde karşılaşılan. lardan farklı özellikler taşımıştır. Statik orta çă̆ teorisi, dinamik güçlerin devamlı faaliyet gösterdiği, reform öncesi ve reform sıra. s1 Avrupa toplumunun ihtiyaçlarını karşılayabilecek güçten yoksun bulunuyordu. Orta çă̆ sınıf düzeni bozulmuş, yeni sınıflar belirmiș ve bunlar çıkarlarını, toplum içinde etkili şekilde savunmaya başlamışlardı. Sermayenin, pazarın ve rekabetin ekonomik hayatta- 
ki rolü gittikçe büyümeye başlamıştı. Roma kilisesinin manevî nüfuzu sarsılmıştı. Yeni düzenin kuruluş sancıları yeni problemler getirmişti.

Luther'in amacı, böyle bir sosyal ortamda yeni bir din ve ah. lâk anlayışımı hâkim kılmak olmuştur. Yaşadığı toplumun şartları, çalkalanmaları, Luther'i yalnızca bir teorici olarak değil, ayni zamanda bir eylem adamı olarak tezini savunmak zorunda birakmıștır. Luther, mülkiyet doktrinini, tabii hukuka değil, fakat din ve ahlák görïșuinde olduğu gibi doğrudan doğruya kutsal kitaba dayandırmak istemiştir. On emirde bulunan «hırsılılk yapmayacak. sın» ilkesinden özel mülkiyetin kutsal kitap öğretisine uygun olduğu sonucuna varmıș, bunun yanında, ticarî faaliyete, özellikle büyük tüccarların ticarì faaliyetine, orta çağ teologları gibi karșı durmak$\tan$ kaçınmamıştır. Faizcilik, Luther için St. Thomas Aquinas için oldư̆̆u kadar haksız kalmıştır. XVI. yüzyılda çiftçinin karşılaștığı ağır ekonomik baskı ve bunun sonucu beliren ve bütün Avrupa'y1 sarsan çiftçi ayaklanmalarmın özellikle Almanyada șiddet kazan. ması, Luther'i bu harekete bütiin guicüyle karșı koymaya götürmüştür. Luther'in mülkiyet konusundaki fikirlerinin çoğunun, çiftçi ayaklanmalarmı destekleyen anabaptist tezin reddine yöneldiği de söylenebilir. Roma kilisesine bütün gücüyle saldıran radikal reformcu Luther, çiftçi ayaklanmalarını daha büyük bir șiddetle suç. lamaktan çekinmemiştir.

Protestan hareketi Almanyada başlica orta sımıflara yönelmiş ve bu sinfflarm sosyal ve ekonomik haklarinı desteklemek amacinı güden bir gelişme göstermiștir. Kilise mallarına el konulmasımı bütün gücüyle destekleyen Luther, köylülerin isteklerini olumlu karşlamamıștır. Böylece Luther'in bir çelişmeye düştügüi söylenebilir. Hem teori hem de eylemle uğraşmak zorunda kalanların çelișmeden kendilerini her zaman kurtaramadıklarına tarih tanıklık etmektedir. Fakat șurasın1 da belirtmek gerekir ki, Luther mülkiyet hakkı üzerinde dururken, sınırsız ve mutlak bir mülkiyet görïșünü benimsemiş değildir. Yani Luther için mülkiyet, faydalanma ve kullanma gerekleri yïzünden meşru bir haktır. Yoksa, XVIII. yüzyıl düșünürlerinin yaptıkları gibi, mülkiyeti mutlak bir hak sayarak bundan faydalanma hakkını çıkarmaya Luther çalıșmamıştır. Faiz kurumunu reddetmesi de, onun ekonomik görüșlerinde, orta çağ geleneğinin ne ölçüde etkili olduğunun başka bir kanıtı sayılabilir.

Calvin'in mülkiyet teorisi, ana çizgileri yönünden Luther'in- 
kinden fazla farklı olmamıştır. O da, Luther gibi, mülkiyetin kutsal kitap öğretisi yönüinden faydalı olduğunu belirtmiştir. Calvin, iyi işleyen bir toplum düzeni yönünden mülkiyet hakkının gerekli olduğuna inanmıştır. Ancak Calvin'in teorisinde, mülkiyet yanında devlet düzenlemesini destekleyen fikirler de yer almıștir. Mülkiyet hakkının sınırlarmı belirtmenin, mülkiyet uygulamasının dogurabileceği haksızlıkları önlemenin, devletin ödevleri arasında bulunduğu kanısını taşımiştır. Cenevrede ekonomik ve ticarî faaliyete konulan smırlamalar, Calvin'in oldukça katı bir devletçiliği benimsediğinin kanıtı sayılmıștır. Calvin, ticaret hayatı hareketli ve zengin Cenevre şehrinde yaşadığı için, ticaret konusundaki tutumu Luther'inkinden değişik olmuștur. Orta çă̆ doktrininin ticarî faaliyetin şüpheli olduğu ve soylu bir çalışma alanı olmadı̆̆ı yolundaki kanısını paylașmamış, tüccarın kazancının da toprak sahibininki gibi kișisel emeğe bağlı olduğunu ve onun kadar haklı sayılması gerektiğini ileri sürmüştür. Faiz konusundaki tutumu da orta çağ teologlarının ve Luther'in görüșünden ayrı bir özellik taşımıştır. Orta çağ teolojisi ve Luther doktrini, faizin her şeklini haksız olarak tanımlarken, Calvin, ticaret faizini desteklemiş, fakiri sömürme amacını güden faizle ödünç para vermeyi ise yermiştir.

Modern kapitalizmin doğușunda protestanlığın etkisi sorunu, Max Weber'in ilginç tezini açıklamasından bu yana, sonu gelmez tartışmalara sebeb olmuștur. Weber, kapitalist üretim şekli ile kapitalizmi ruhunu dikkatle birbirinden ayırmaya çalıșmış, kapitalizmin başlıca kapitalist ruhun bir sonucu olduğu üzerinde durmuștur. Kapitalist ruhun en önemli iki özelliğinin para kazanmak için para kazanmak eğilimi ve gösterișten, israftan uzak mutedil bir yașama olduğunu ileri sürmüștür. Modern kapitalizm ruhuna ait bu iki özelliğin kaynağını araştırırken Weber, büyü ve din fikirle. rinin ve bunların yarattı̆̆ı sosyal ve ekonomik ahlâkın insanların yalnızca sosyal davranışlarını etkilemekle kalmadığı, ayni zamanda toplum düzeninin objektif esaslarını belirtmede de din inancının önemli bir fonksiyon ifa ettiği yolundaki sosyoloji anlayışından hareket etmiştir.

Weber, büyük kapitalist müteşebbislerin protestan ülkelerde, katolik memleketlere göre daha fazla olduğu yolundaki gözlemin. den yararlanarak, teorisinin temeli yaptığ kapitalist ruhun, yukarıda açıkladığımız iki özelliğinin protestan öğretisi ile en çok Calvin'in görüssleri ile ilgili bulunması gerektiğini savunmuştur. 
Protestanlığın, Tann ve kişi arasındaki ilişkide kilisenin aracllı̆̆ını kald̀ırdığını, Luther'in ancak inanç aracılı̆̆ı ile Tanrıya ulaşmanın mümkün olabileceğini söylediğini, bir de her insanın kendisini Tanrı tarafından gösterilen çalışmaya ve işe bağlaması$\mathrm{n}_{1}$ öğüt verdiğini, Calvin'in ögretisinde ise, insanın kurtulușa (sal. vation) ulaşmak için, kendini işine vermesinin savunulduğunu, başlangıçta iş ve çalışmanın ahlâki ödevlerin yerine getirilmesi olarak anlaşıldığını, fakat sonradan çahışma kavramının tamımen insanın kendisini üzerine aldığı işe yöneltmesi olarak değerlendirildiğini, çalışmak için çalışmanın tavsiye edildiğini, Weber açıklamıștır. Gene Weber'e göre çalıșmak için çalıșma ilkesi, zamanla para kazanmak için para kazanma olarak yorumlanmıștır.

Weber, bundan başka, katolik felsefesinin manastır hayatı ilkesini reddeden Calvin'in, sözii geçen ilkeyi dünya hayatına aktardığını, insanlara israf ve gösterișten uzak, disiplinli bir yașama yolu tavsiye ettiğini ve bu hayat șeklinin kapitalist ruhun ikinci unsuru olan disiplin fikrini geliștirdiğini ileri sürmüştiiir.

Böylece Weber'e göre, insanın kendisini ișine vermesi, üretimin çoğalması, disiplinli, israf ve gösterișten uzak bir hayat yaşa. ması, tüketimin azalması sonucunu doğurmuș ve bu iki faktörün birleșmesi, kapitalist gelișmenin vazgeçilmez şartı olan sermaye toplanmasını sağlamıştır.

Weber'in vardığı sonuç, protestan ülkelerde kapitalizmin, kapitalist ruhun egemenliği dolayısıly süratli bir gelişme gösterdiği ve kapitalizm ile Calvin'in öğretisi, özellikle bu öğretiyi Anlo - Sakson ülkelerinde yayan puritanizm arasında organik bir ilişsinin bulunduğudur.

Kısaca özetlediğimiz bu tez, düşüncemize göre, gerçeği yansıtmaktan uzak bulunmaktadır. Birinci ve İkinci bölümlerde açıklamaya çalıștığımız gibi, Avrupa toplumunda kapitalizme ait temel özellikler, çekirdek halinde olsa bile, reform hareketinden önce var. d. XV. asırda, yani reform hareketinden aşağı yukarı yüz yıl önce, ticaret hayatında büyük şirketlerin ve tekellerin egemen olduğu bilinmektedir. Şu halde Robertson'un haklı olarak belirttiği gibi, kapitalizm kendisinden sonra doğmus olan bir akımın etkisi altımda kalmıs ve onun tarafından yaratılmıs olamaz. Fanfani de daha önce açıkladığımız gibi ayni görüşü paylaşmaktadır.

Diger taraftan, kapitalist ekonominin protestanlik tarafından yaratıldı ğg kabul edilirse, feodal sosyal düzen ruhunun da Avrupa- 
da feodalizmin doğduğu orta çağ başlangıcinda katolik inancı tam ve kesin bir egemenliğe sahip bulunduğuna göre, onun etkisi altında belirdiğini ve geliştiğini söylemenin kabil olması gerekir. Böyle bir iddianın, gerçekle ilişkisi olabileceği, hatta ciddi sayılabileceği son derece șïphelidir. Bundan başka, belli bir ekonomi sistemi olan kapitalizmi mutlaka din öğretisi ile açklarakak gerekirse, Werner Sombart'ın kapitalizm ruhunun yahudilikle ilgili olduğu yolundaki görüşüne eşit ölçüide hak vermemek için herhangi bir sebeb yoktur. Çünkü, Weber'in mantı̆̆ı kullanılarak kapitalist müteșebbisler arasında yahudilerin sayısının az olmadığ, bu sebeble yahudilik ahlâkı ile kapitalizm arașında bir ilişkinin bulunması gerekebileceği savunulabilir. Bütün bu örnekler Weber'in temelde bir yanlışlığa düștüğünün kanıtı olabilir.

Robertson'un söylediği gibi, kapitalist ruhu doğuran en önemli sebebin kapitalizmin kendisi olduğunu belirtmekte herhangi bir yanlışlık yoktur, Max Weber'in tezinde doğru olan, kalvinizmin kısmen değişmiş bir şekli olan puritanizmin, Anglo Sakson ülkelerinde, kapitalizmi ahlâki açıdan desteklemek hususunda belli bir rol oynadı̆̆ıdır. Ancak bu rolü, kapitalist düzenin puritan doktrin üzerinde yaptığı etki ile açıklamak şüphesiz kabil bulunmaktadır ve böyle bir yorum, puritan ahlâk görüşünün XVII. ve XVIII. yüzyıllarda geçirdiği değișikliği açıklamak yönünden de yararlı olabilir. 